\title{
INWAZJA CENTAURÓW*
}

Theodore Roszak

W naszym „dzisiaj”, we wszelkim „dzisiaj”, współistnieją rozmaite pokolenia, a wzajemne relacje między nimi, nawiązywane odpowiednio do wieku ich członków, tworzą dynamiczny system przyciagania i odpychania, porozumienia i sporu, który w każdym konkretnym momencie tworzy historyczną rzeczywistość życia ${ }^{1}$.

Zgadzając się z Ortegą że sztafeta pokoleń stanowi znaczący element historycznej zmiany, musimy również przyznać, iż młodzież może się ograniczać do reorganizowania odziedziczonej kultury w niewielkim jedynie stopniu. Młodzi ludzie moga się zadowalać powierzchowną zmianą mody, wprowadzaną z najzwyklejszej przekory bądź kaprysu. Tym, co szczególne w przemianie pokoleniowej, która przechodzimy obecnie, jest jej skala i głębokość odsłanianego przez nią antagonizmu. Nie byłoby wcale przesadą określić to, czego powstanie obserwujemy właśnie wśród młodych, mianem „kontrkultury”. W znaczeniu: kultury tak radykalnie oderwanej od podstawowych założeń głównego nurtu naszego społeczeństwa, że tracącej w oczach wielu wszelkie podobieństwo do kultury w ogóle, nabierającej za to niepokojących cech barbarzyńskiej inwazji.

Natychmiast narzuca się pewien obraz: inwazja centaurów uwieczniona na rzeźbach z frontonu świątyni Zeusa w Olimpii. Pijane i rozsierdzone centaury wdzierają się w sam środek trwających właśnie obchodów cywilizowanego święta. Wtedy jednak interweniuje sam srogi Apollo, strażnik ortodoksyjnej kultury, napomina i przepędza intruzów. To obraz bardzo nośny, jako że przywołuje to, co stanowi przerażające doświadczenie w dziejach każdej cywilizacji: doświadczenie radykalnego rozłamu kulturowego, starcia niemożliwych do pogodzenia koncepcji życia. Starcia, z którego Apollo nie zawsze wychodzi zwycięsko.

* "Invasion of Centaurs" from THE MAKING OF A COUNTER CULTURE. Copyright (C) 1968, 1969 by Theodore Roszak. Reprinted by permission of ICM Partners.

1 Ortega y Gasset J. 1959. Man and Crisis, tłum. M. Adams, Allen \& Unwin, London, s. 45. 
Toynbee zidentyfikował w tego rodzaju kulturowych rozłamach dzieło wydziedziczonego „proletariatu”, opierając się na przykładzie roli wczesnych chrześcijan w Cesarstwie Rzymskim - czyli klasycznym przykładzie sytuacji, w której Apollo zostaje pokonany przez niesforne centaury. Porównanie z chrześcijanami należy do tych, które wielu młodych przywołuje w pierwszej kolejności, z większą być może słusznościa, niż są gotowi przyznać ich liczni krytycy. Na wskroś wyobcowana przez własny etos i pozycję społeczną z nurtu kultury oficjalnej pierwotna wspólnota chrześcijańska stworzyła na podstawie judaizmu i kultów misteryjnych kulturę mniejszościową, która z konieczności musiała się wydawać grecko-rzymskiej ortodoksji zwykłą niedorzecznością. Lecz to właśnie ów absurd, wcale nie wywołując w swych głosicielach poczucia wstydu czy kompromitacji, bardzo szybko trafil na sztandary owej wspólnoty.

Napisane jest bowiem - chelpił się św. Paweł - Wytracę mądrość mędrców, a przebiegłość przebiegłych zniweczę... Tak więc, gdy Żydzi żądają znaków, a Grecy szukają mądrości, my głosimy Chrystusa ukrzyżowanego, który jest zgorszeniem dla Żydów, a głupstwem dla pogan, dla tych zaś, którzy są powołani, tak spośród Żydów, jak i spośród Greków, Chrystusem, mocą Bożą i mądrością Bożą. To bowiem, co jest głupstwem u Boga, przewyższa mądrością ludzi, a co jest słabe u Boga, przewyższa mocą ludzi (1 Kor. 1:19, 22, 27).

Przytoczyłem ustęp dobrze znany, w dodatku zaczerpnięty ze źródła, które obecnie traktujemy z nadmiernym wręcz szacunkiem. Fragment do tego stopnia znajomy i tak patetyczny, że łatwo stracić z oczu, z jak agresywnie wywrotowa deklaracja mamy tu do czynienia... jak bardzo owych kilka zdań nabrzmiałych jest niepohamowaną wzgardą dla dawnej, bogatej w osiagnięcia kultury. A czyjaż to była wzgarda? Ludzi, których określilibyśmy mianem zupełnych zer, szumowin, grupy, której własna kontrkultura była - na tym wczesnym etapie - niewiele więcej niż garścią sugestywnych idei, zlepkiem kilku prostych symboli i rozpaczliwej tęsknoty. I właśnie tęsknota, poczucie braku odgrywało w niej największą rolę, jako że nawet cała wspaniałość grecko-rzymskiej cywilizacji nie była w stanie zrównoważyć duchowego wyjałowienia, które stało się pożywką chrześcijaństwa. Ponieważ jesteśmy dzisiaj w stanie spojrzeć na te procesy z olbrzymiego dystansu i wiemy, do czego chrześcijańskie scandalum ostatecznie doprowadziło, porównanie $z$ wciąż jeszcze raczkująca kontrkulturą młodych musi wydawać się cudaczne. Z drugiej jednak strony, wszelkie rewolucyjne zmiany są nie do pomyślenia, dopóki nie nastapią... po czym postrzegamy 
je z kolei jako nieuniknione. Kto - za czasów Pawła - mógł był przewidzieć, co wyrośnie na gruncie bezczelnej wrogości grupki obdartych malkontentów? I jak wyglądałby rodzący się ruch chrześcijański oglądany bezlitosnym okiem mass mediów, gdyby takowe wówczas istniały? Czy przetrwałby w ogóle napór ich zmasowanego zainteresowania?

Być może młodzież w tym pokoleniu nie dysponuje energia konieczną do przeprowadzenia wymarzonej przez siebie, epokowej transformacji, lecz nie łudźmy się - oni nie zadowola się niczym mniej doniosłym. Fraza „całkowite odrzucenie” wykwita na ich ustach łatwo, często zanim jeszcze rozum podsunie niejasny choćby obraz nowej kultury, której zadaniem miałoby być zastąpienie porządku dotychczasowego. Jeżeli w etosie Black Power zawarte jest cokolwiek, co przyciaga nawet białych odtrąconych [disaffiliates], którzy nie moga do tego ruchu dołączyć osobiście, jest to poczucie, że ideologia Black Power w pewien sposób implikuje zupełnie nowy sposób życia: kultura czarnych, czarna samoświadomość... czarna dusza, wszystko to pozostaje w całkowitej niezgodzie ze społeczeństwem białych i z tego właśnie powodu pozwala odczuwać agresywną wręcz dumę. Owszem, ruch Black Power wzniósł niejedną barierę oddzielającą młodzież białą od czarnoskórej, lecz ponad tymi zasiekami wciąż słychać zdania wypowiadane we wspólnym języku. Oto, dla przykładu, mamy Bobby’ego Seale'a z oaklandzkiego oddziału Czarnych Panter, przemawiającego na spotkaniu Centrum Edukacji Uczestniczącej, zorganizowanym we wrześniu 1968 na uniwersytecie w Berkeley. Kryzys, z jakim mieliśmy tam wówczas do czynienia, wywołany został decyzją kierownictwa Uniwersytetu Kalifornijskiego, wzbraniająca rzecznikowi Czarnych Panter wstępu na kampus. Dla Seale’a, podobnie jak dla reszty studentów, kwestia miała głębsze kulturowe implikacje. Okazało się, że z tym jednym aktem administracyjnej cenzury w jakiś sposób wiąże się wszystko - sens i znaczenie władzy, osobistej tożsamości, judeochrześcijańskiej etyki, a także wolności seksualnej.

Archie i Jughead nigdy nie całowali się z Veronicą i Betty². Superman ani razu nie pocałował Lois Lane. Czujemy się zmęczeni życiem według komiksowych wzorców. Adam powinien był obronić rajski ogród przed jego wszechmocnym zarządca. Życie, wolność i dążenie do szczęścia nie znaczą dla mnie zupełnie nic, o ile nie mogę bezpiecznie wrócić do domu i spokojnie wraz z żoną zająć się zaludnianiem Ziemi ${ }^{3}$.

\footnotetext{
2 Archie Andrews, Forsythe „Jughead” Jones, Betty Cooper i Veronica Lodge - amerykańskie nastolatki, fikcyjni bohaterowie popularnych, wydawanych od lat 40. XX stulecia serii komiksowych wydawnictwa Archie Comic Publications, Inc. (przyp. tłum.).

3 Z nagrania wystapienia nadanego przez radio KPFA (Berkeley) 24 września 1968.
} 
Na pierwszy rzut oka nie widać być może zbyt wyraźnie, co tego rodzaju nastroje (a stanowily one istotę cytowanego przemówienia) maja wspólnego z problemem akademickiej wolności. Słuchacze zrozumieli jednak Seale’a bez najmniejszego problemu. Bez trudu przyjęli, że autorytaryzm naszego społeczeństwa odciska swe piętno - jawnie bądź w sposób bardziej subtelny - na wszystkich poziomach życia, od komiksowych pasków po chrześcijańską teologię, od uniwersyteckiej sali wykładowej po zacisze domowej sypialni. Co więcej, zebrani byli równocześnie gotowi odrzucić całość kultury ufundowanej na tak plugawym przymusie.

Przyjrzyjmy się innemu przykładowi apokaliptycznych ciagot, które nawiedzają naszą młodzież. Gdy na początku 1968 otwarty został Antyuniwersytet Londyński - pierwszy brytyjski odpowiednik naszych wolnych uniwersytetów - informator tej uczelni pełen był zachęt do uczestniczenia w zajęciach poświęconych „,antykulturom”, ,antyśrodowiskom”, „antypoezji”, „antyteatrowi”, „,antyrodzinom” oraz „kontrinstytucjom”. Najwyraźniej wszystko, co miało do zaoferowania społeczeństwo dorosłych, okazało się już niemożliwe do przyjęcia. Rozgorączkowany radykalizm szkoły miał ostatecznie osiagnać taki poziom, że nawet usankcjonowana wiekowa tradycja relacja student - wykładowca znalazła się pod ostrzałem jako niedopuszczalny przejaw tendencji autorytarnych. Jako taka więc i ona została wyrugowana, w oparciu o założenie, że nikt nie ma już nic sensownego do przekazania młodym, którzy postanowili swój system edukacyjny zbudować od zera. Niestety - i nie jestem pewien, czy było to wydarzenie bardziej tragiczne, czy raczej komiczne - tego ostatecznego aktu radykalnej restrukturyzacji uczelnia przetrwać nie zdołała.

Tak gorącemu niezadowoleniu zawsze towarzyszy ryzyko wyparowania, przeobrażenia się w bezkształtny opar - w którego kłębach niełatwo odróżnić chiliastyczne objawienia od najzwyklejszych bredni.

Przykładem typowej strawy serwowanej przez Antyuniwersytet może być jedno z „dań” jego menu, cykl zajęć „Od komiksu do tańca Siwy. Duchowa amnezja i fizjologia samowyobcowania”. (W tym miejscu ponownie można dostrzec cudaczne, lecz sprytne skojarzenie kultury komiksowej i rozwiniętej religii.)

Opis kursu: Niczym nieskrępowana parada sytuacji otwartych. Wysoce istotne będą wibracje pojawiające się w trakcie. Badanie Kosmosu Wewnętrznego, odtrącanie narzuconych uwarunkowań ludzkiego robota, znaczenie psychotropów i transformacja człowieka kultury europejskiego Zachodu. Materiał źródłowy: Artaud, Zimmer, Gurdżijew, W. Reich. K. Marks, gnostycy, teksty sufizmu i tantryczne, autobiogra- 
ficzne relacje dotyczące szaleństwa i ekstatycznych stanów świadomości - pop art i dwudziestowieczna proza.

Problematyka, istotnie, poważna. Niemniej powyższy przykład znakomicie ilustruje panujący na wolnych uniwersytetach styl. Tego rodzaju ekscentryczne burze mózgów, moderowane przez ledwie dwudziestoletnich instruktorów, dość często degenerują się w półartykułowaną, bezkrytyczną afirmację wszystkiego, co nowe, dziwne i hałaśliwe; w powierzchowne przemykanie się po ideach, najsilniej przywodzące na myśl zabawy niemowląt z kolorowymi, obcymi jeszcze przedmiotami. Apetyty dopisuja i skłaniają do nieskrępowanej wszystkożerności, lecz pilnie domagają się przewodnictwa dojrzałego umysłu. W kolejnych rozdziałach moim głównym celem będzie krytyczne przyjrzenie się kilku najważniejszym postaciom, zajmującym się obecnie właśnie tym. Niemniej już na wstępie chcę jasno przedstawić własny punkt widzenia. Otóż sądzę, że - mimo ich szaleństw - owi młodzi centaurowie zasługują na zwycięstwo w starciu z broniącymi naszego społeczeństwa Apollinami. Albowiem ortodoksyjna kultura, przeciw której występuja, cierpi na śmiertelną, zakaźną chorobę. Klasycznym objawem owej przypadłości jest widmo termonuklearnej zagłady, w której cieniu wszyscy trwożnie żyjemy. Kontrkultura występuje przeciwko podstawom tego absolutnego zła, zła niedającego się zdefiniować wyłącznie poprzez fakt istnienia bomby, lecz raczej przez totalny ethos bomby, ethos, w którym tkwia - maskując go za pomoca pomysłowych racjonalizacji - nasza polityka, powszechnie przyjęta moralność, życie gospodarcze, a także działalność intelektualna.

Należymy do cywilizacji pogrążonej w niezachwianym oddaniu idei ludobójstwa, obłąkańczo igrającej z ewentualnością całkowitej eksterminacji własnego gatunku. Jakże ochoczo tłamsimy własne poczucie człowieczeństwa, by - choć przez jeden dzień - udawać, że skala tej grozy może być czymś „normalnym”, czymś „,koniecznym”! Za każdym razem, kiedy czujemy chęć, by osądzić, zmodyfikować czy skwitować protesty młodych ostrożnym „tak, ale...”, powróćmy do prostego faktu stanowiącego probierz zasadniczej zbrodniczości technokracji: zakresu, w jakim technokracja domaga się, by - w imię postępu i rozumu - niewyobrażalne stało się wyobrażalnym, a niedopuszczalne - dopuszczalnym.

Jeżeli więc uznamy, że kontrkultura jest - jak będę tu argumentował owym zdrowym instynktem, który zarówno na poziomie jednostkowym, jak i politycznym skłania do niezgody na ten dokonywany z zimną krwia gwałt na naszej ludzkiej wrażliwości, to powinno stać się jasne, z jakiego powodu konflikt między młodzieżą a dorosłymi wybuchł w naszych 
czasach z taką siłą i zarazem dlaczego sięga tak głęboko. W sytuacji historycznego zagrożenia, niebezpieczeństwa zdecydowanie bezprecedensowego, okazujemy się dziwnym, ograniczonym przez własną kulturę gatunkiem, którego biologiczny instynkt samozachowawczy wyraża się pokoleniowo. To właśnie młodzież - ze swym jasno dostrzegającym oczywistość spojrzeniem - musi przekształcić śmiercionośną kulturę poprzednich pokoleń, i to w rozpaczliwym pośpiechu.$$
* * *
$$

Zajęcie pozycji, których zamierzam tu bronić, jest krokiem niewątpliwie ryzykownym. Albowiem gdy w społeczeństwie dojdzie już do powstania kulturowego rozziewu, niczego nie da się zagwarantować. Wszystko, co wydarzy się wśród odizolowanej owa przepaścią mniejszości, może okazać się szlachetne, ale równie dobrze nikczemne. Absurdowi prymitywnego chrześcijaństwa można sprawiedliwie oddać przynajmniej jego zdolność wytworzenia wspaniałych dzieł rozumu i mistycznego oglądu rzeczywistości, jak również ideału uświęconej służby. Z drugiej strony, wyalienowani maklerzy giełdowi i tapeciarze w Niemczech po I wojnie światowej wycofali się z posępnymi minami do swoich piwiarni, gdzie dyskutując o skretyniałych odmianach antropologii, gotowali zgrozę Buchenwaldu. Podobnie rzecz się ma z izolowanymi mniejszościami współczesnej Ameryki. Znajdujemy wśród nich Hell's Angels i The Minutemen, grupy, po których nie można się spodziewać wzniosłości lub subtelnoścít.

Wracając do naszej wyobcowanej młodzieży: jak winniśmy scharakteryzować ową kontrkulturę, której chaotyczne zręby zaczęli właśnie tworzyć młodzi? Rzecz jasna, nie można na to pytanie odpowiedzieć, dobywając z zanadrza egzemplarz jakiegoś manifestu, jednomyślnie zatwierdzonego przez kontestujące pokolenie: kontrkultura jest ruchem, któremu daleko do wewnętrznej dyscypliny. Stanowi coś na kształt średniowiecznej krucjaty: procesji zróżnicowanej, nieustająco pozostającej w ruchu, a także bezustannie zasilanej i uszczuplanej po drodze.

${ }^{4}$ Hell's Angels - właściwie Hells Angels Motorcycle Club (Klub motocyklowy Aniołowie Piekieł). Powstały w 1948 roku w Kalifornii gang motocyklowy, oskarżany o rozboje, handel narkotykami i kradzieże, otwarcie kierujący się ideologią rasistowską.

The Minutemen - zbrojna, antykomunistyczna, skrajnie prawicowa organizacja założona na początku lat 60. XX wieku przez Roberta DePugha. Jej członkowie przygotowywali się (magazynując broń i sprzęt) do stawienia zbrojnego oporu zbliżającej się amerykańskiej rewolucji komunistycznej. W 1968 roku DePugh został oskarżony o planowanie napadu na bank oraz złamanie przepisów dotyczących posiadania broni palnej. Po wpłaceniu kaucji uciekł i ukrywał się do roku 1969 (przyp. tłum.). 
Często jednak zdarza się jej odnajdować własną tożsamość w mgławicowym symbolu lub piosence, która pozornie nie głosi nic ponad: ,Jesteśmy wyjątkowi... Jesteśmy inni... Zostawimy za sobą stary, zepsuty świat”. Niektórzy dołączają do tej armii jedynie na moment, wystarczająco jednak długi, by podjąć oczywistą i bezpośrednią walkę: bunt na kampusie, demonstrację antywojenną lub przeciwko niesprawiedliwości rasowej. Część młodych kontestatorów ograniczy się do zamachania maleńką choragiewka przeciw bestialstwu technokracji, być może zdobęda się również na wpięcie w klape znaczka z hasłem „Człowiek - nie drzeć, nie bić, nie maglować”. Inni, bezpowrotnie i świadomie przekroczywszy granice społecznej akceptacji, nie maja już innego wyboru, jak zmierzać prosto ku swemu Świętemu Miastu. Tych osób nie zawrócą z raz obranej drogi żadne fragmentaryczne reformy tudzież pomniejsze zmiany porządku, jaki zostawili za sobą.

Gdzie jednak leży owo wolne od technokracji Święte Miasto - i jakim się okaże?

To częsty temat rozmów na szlaku, niektórzy prawią sensownie, inni głupio. Wielu uczestników pochodu pewnych jest wyłącznie tego, jak to miasto wyglądać nie może. Bardziej obyta intelektualnie mniejszość - pośród niej postacie omawiane w kolejnych rozdziałach - wykazuje się dostatecznym stopniem wnikliwości, by dostrzec punkt, w którym kończy się technokracja, a zaczynają terytoria Nowej Jerozolimy: nie na poziomie klasy społecznej, partii lub instytucji, lecz raczej na pozarozumowym (non-intellective) poziomie osobowości, z której owe społeczno-polityczne formy wyrastaja. To oni zrozumieli - a wielu ich naśladowców uznaje ową wizję za pociagająca - że budowa dobrego społeczeństwa nie jest zadaniem społecznym, lecz przede wszystkim psychologicznym. Tym, co sprawia, że kontestacja naszej współczesnej młodzieży staje się zjawiskiem kulturowym, a nie po prostu ruchem politycznym, jest fakt, iż uderza ona poza obszar ideologii, wybiega na teren świadomości, próbując przekształcić nasze najgłębsze poczucie tożsamości, relacji z innymi i środowiskiem.

Psychiatra R. D. Laing trafnie ujmuje ducha tego projektu, twierdząc: „Nie potrzebujemy teorii, lecz raczej fundującego teorię doświadczenia”. Takie rozgraniczenie teorii i bezpośredniego doświadczenia - już samo w sobie rzucające wyzwanie analitycznej jasności jako podstawie wiedzy i przeświadczeń - musi z konieczności wzmagać nutę antyintelektualną. Ów ton daje się słyszeć jeszcze wyraźniej, gdy Laing przechodzi do definiowania swego celu, „prawdziwego zdrowia psychicznego”, jako stanu: 
polegającego w pewnym sensie na rozpadzie normalnego ego, owego fałszywego ja, fachowo dopasowanego do naszej wyalienowanej rzeczywistości społecznej; rozpadzie prowadzącym do ujawnienia się „wewnętrznych” archetypicznych pośredników (mediators) boskiej mocy, poprzez tę śmierć stającym się odrodzeniem oraz finalnym ustanowieniem nowego sposobu funkcjonowania ego, które miast jej zdrajcą stanie się sługą boskości ${ }^{5}$.

Psychiatria posługujący się tego rodzaju językiem wykracza daleko poza granice tradycyjnie przyjętej naukowej przyzwoitości. Skoro jednak kontestująca młodzież obdarza uwaga postacie pokroju Lainga (jednego z czołowych mentorów rodzącej się brytyjskiej kontrkultury), czyni tak z pewnością dlatego, że widziała już wielu ludzi o niekwestionowanej inteligencji, powodowanych światłymi motywacjami, którzy stali się apologetami zdehumanizowanego porządku społecznego. Cóż takiego sprawiło, że tak liczni przedstawiciele naszej nauki, nasi akademicy, najbardziej obyci i wytworni przywódcy polityczni, a nawet nasi dzielni, niedoszli rewolucjoniści, pogodzili się z technokracja - pogodzili, lub wręcz z radością oddali się na jej usługi? Bez wattpienia nie był to niedostatek inteligencji tudzież ignoranckie podejście do humanistycznych wartości. Problem tkwi raczej w tym, że technokratyczne założenia dotyczące natury ludzkiej, społeczeństwa i przyrody zniekształciły doświadczenie tych ludzi u samego źródła, wpływając tym samym na ukryte przesłanki, na których opiera się praca intelektu i osądy etyczne.

Aby zatem wykorzenić owe deformujące założenia, należałoby obalić światopogląd naukowy, wraz z jego mocno okopanym uwielbieniem modelu świadomości egocentrycznej, zredukowanej do zachodzących w mózgu (cerebral) procesów. W jego miejsce musi pojawić się natomiast kultura nowa, w ramach której o dobru, prawdzie i pięknie rozstrzygałyby pozarozumowe władze ludzkiej osobowości - te jej możliwości, które czerpia moc z wizjonerskiej wspaniałości i doświadczenia ludzkiej wspólnoty.

Moim zdaniem kulturowa przepaść, jaką obecny konflikt pokoleniowy wykopuje pomiędzy sobą a technokracją jest równie wielka, jak wielki w swych konsekwencjach (bo, naturalnie, nie od razu pod względem doniosłości historycznej) był rozłam pomiędzy grecko-rzymską racjonalnością i chrześcijańskim misterium. Oczywiście, na przestrzeni ubiegłych dwóch stuleci społeczeństwo Zachodu inkorporowało już liczne mniejszości, których wrogość wobec światopoglądu naukowego była podobnie

${ }^{5}$ Laing R. D. 1967. The Politics of Experience and The Bird of Paradise, Penguin Books, London, s. 119. 
radykalna i które nie dały się zasymilować równie łatwo jak naczelne wspólnoty religijne, ogarnięte coraz to silniejszym pragnieniem uzyskania miana postępowych. Byli teozofowie i fundamentaliści, spirytualiści i wyznawcy teorii płaskiej Ziemi, okultyści i sataniści... W istnieniu między nami takich antyracjonalistycznych żywiołów nie ma niczego nowego. Nowym elementem jest fakt, że radykalne odrzucenie reprezentowanych przez naukę i technologię wartości pojawia się tak blisko centrum naszego społeczeństwa, miast na jego nieistotnych peryferiach. Za polityką świadomości stoi młodzież klasy średniej, a prowadzi ją żywiołowo, wytrwale i agresywnie - do tego stopnia, że dokonuje inwazji technokratycznych fortec akademickiego nauczania z zamiarem ich przejęcia.

Zadanie scharakteryzowania pozarozumowych władz osobowości, które z takim zapałem podjęła nasza młodzież, żadną miarą nie jest przedsięwzięciem łatwym. Aż do nastania epoki psychoanalizy słownik, za pomocą którego nasze społeczeństwo próbowało prowadzić dyskurs dotyczący pozarozumowych aspektów życia, był żałośnie wręcz ubogi. Mistycy i romantycy, którzy działali najbliżej mrocznych stron umysłu, zaopatrzyli nas w pewien repertuar błyskotliwych metafor i obrazów, za pomoca których objaśniali swe doświadczenie. Podobnie tradycje hinduistyczna i buddyjska dostarczają słownika znakomicie nadającego się do rozmowy o świadomości pozarozumowej - jak również liczne techniki pozwalające dotrzeć do zawartych w niej treści. Racjonalność naukowa odrzuca jednak metafory i terminologię mistyczną w ten sam sposób, w jaki automat z napojami wypluwa fałszywe monety ( $\mathrm{z}$ jednym, znaczącym, wyjątkiem: metafora ,prawa” naturalnego, bez której rewolucja naukowa nie zdołałaby nawet wzbić się do lotu). Ten stan rzeczy sprawia, że brakuje nam słownictwa, kiedy tylko wkroczymy w tę dziedzinę doświadczenia, w której artyści i mistycy upatrują najwyższej wartości egzystencji ludzkiej. W dyskusji dotyczacej tego, co pozarozumowe, nie pomaga nawet wspomniana psychoanaliza, przede wszystkim dlatego, że jej podejście obciążone jest mechanicystyczną terminologia oraz zobiektywizowanym dystansem, to jest skłonnością do nachalnego badania „z zewnątrz” zamiast doświadczania „od wewnątrz”. Przyglądając się intelektualnej historii pokolenia, które wydało na świat Freuda, Sorela, Webera i Durkheima - pierwszej generacji, która podjęła prawdziwie, we własnej ocenie, naukowe badania irracjonalnych motywacji człowieka - H. Stuart Hughes zauważa:

Myśliciele społeczni lat 90. XIX stulecia zajmowali się tym, co irracjonalne, wyłącznie po to, by dokonać egzorcyzmu tej sfery. W swoich 
badaniach poszukiwali sposobów na jej ujarzmienie i skanalizowanie z zamiarem konstruktywnego wykorzystania dla ludzkich celów ${ }^{6}$.

W miarę rozprzestrzeniania się naukowej bądź quasi-naukowej myśli w naszej kulturze, od nauk fizycznych, przez tak zwane nauki behawioralne, po studia humanistyczne i artystyczne, coraz bardziej uwidaczniała się tendencja do obejmowania wszystkiego, co nie w pełni i niezbyt klarownie poddawało się świadomej - empirycznej bądź matematycznej - manipulacji, jedną, czysto negatywna, wszechogarniającą kategorią (stanowiąca w praktyce kulturowy odpowiednik kosza na śmieci), a mianowicie kategorią „,nieświadomości”... bądź „tego, co irracjonalne”..., „mistyczne”... lub „czysto subiektywne”. Osoba działająca w oparciu o tego rodzaju niedookreślone stany świadomości jest $\mathrm{w}$ najlepszym razie zabawnym ekscentrykiem, w najgorszym - zwykłym szaleńcem. I na odwrót, zachowanie normalne, wartościowe, produktywne, świadczące o psychicznym zdrowiu, zachowanie społecznie akceptowalne, możliwe do intelektualnej obrony, przyzwoite i praktyczne, nie może mieć ze sfera subiektywności absolutnie nic wspólnego. Zalecając komuś, by „był rozsądny”, „nie wygadywał bzdur”, „zszedł na ziemię”, radząc, by „trzymał się faktów” i „był realista”, mamy w istocie na myśli to, że powinien unikać mówienia o swoich uczuciach „wewnętrznych” i patrzeć na świat w sposób podobny do perspektywy budowniczego oceniającego architektoniczny projekt tudzież fizyka obserwującego ruchy atomów. Czujemy, że to z tego drugiego nastawienia i stanu świadomości wypływają rzeczy wartościowe - wiedza, rozwiązania problemów, skuteczna realizacja zamierzeń, pieniądze, władza - podczas gdy pławienie się w „czczych uczuciach” prowadzi jedynie do nieproduktywnego rozpasania. Co bardziej wyrafinowani spośród nas moga, owszem, przyznać artystom prawo do marzeń i snów na jawie. Świat jednak, o czym wie każdy praktycznie myślący człowiek, mógłby się spokojnie obyć bez wierszy i obrazów, za to zupełnie nie poradziłby sobie bez zapór na rzekach, szos, bomb i konkretnej polityki. Sztuką można się zajmować w czasie wolnym - pozostałym człowiekowi po uporaniu się z twardymi wymogami rzeczywistości ${ }^{\top}$.

${ }^{6}$ Hughes H. S. 1958. Consciousness and Society, Vintage Books, New York, s. 35-36. Pośród
głównych myślicieli okresu wyłącznie Bergson i Jung, nie licząc osobowości środowiska
artystycznego, traktowali pozarozumową stronę ludzkiej natury z intuicyjna sympatią. Kto
jednak, we wspólnocie naukowo-akademickiej, uważa ich obecnie za ,głównych myślicieli’?
7 Można oczekiwać pewnego złagodzenia kompulsywnie utylitarnej racjonalności, jakie
powinno wyrosnąć na podłożu tej nowej i hojnie dotowanej sfery badań nad snem, prze-
konujących nas o nieodzowności doświadczenia pozarozumowego. Fascynujący przegląd 
W późniejszych rozdziałach wrócimy do pełniejszego namysłu nad światopoglądem naukowym i jego niedostatkami. Powyższe miało jedynie naświetlić kłopot, jaki ma kontrkultura z samym choćby dookreśleniem swego projektu. Wycofała się na pozycje tak dalekie od głównego prądu kulturowego, że praktycznie nie może się wypowiadać, nie narażając się jednocześnie na zarzut posługiwania się obcym językiem. W świecie, w którym coraz liczniejsi uważają społeczeństwo za podrzędny element gigantycznego mechanizmu technologii, wymagającego bezustannej i niezwłocznej koordynacji z centrum decyzyjnym, młodzież zaczyna mówić o sprawach tak niepraktycznych jak ,wspólnota” czy „demokracja uczestnicząca". Młodzi cofają się w ten sposób do stanu relacji międzyludzkich charakteryzującego poziom wiosek i szczepów. Twierdzą że polityka może się rozgrywać jedynie za pośrednictwem głęboko osobistych konfrontacji, jakie możliwe są w ramach tych przestarzałych obecnie form społecznych. Gdzie mają znaleźć zrozumienie dla tak swojskiego i prostego ideału $\mathrm{w}$ świecie zdominowanym przez wielkie polityczne abstrakty, przystrojone w połyskliwe, propagandowe symbole, slogany i badania statystyczne, abstrakty takie jak państwo, partia, korporacja, obszary miejskie, wielkie przymierze, wspólny rynek, system socjoekonomiczny...? Pełna życia świadomość mężczyzn i kobiet takich, jakimi sq w swej codzienności, zniknęła z naszej kultury zupełnie, wyparta przez owe górnolotne, napuszone wytwory jaźni (figments). Utrzymywać, że istotą uspołecznienia (sociability) jest proste i jakże piękne wspólnotowe otwarcie się na drugiego człowieka, a nie dążenie do realizacji kolejnych cudów techniki i gospodarki - czyż nie jest to jawnym głoszeniem absurdu?

I dalej, podtrzymywać tezę o wyższości władz pozarozumowych i jednocześnie kwestionować wszystko, co nasza kultura ceni pod pojęciami „,rozumu” i „rzeczywistości”? Zaprzeczać, że naszym prawdziwym ja jest ten drobny, twardy atom skondensowanej obiektywności, którym codziennie

tej pracy znaleźć można w Gay G. Luce i J. Segal, Sleep (Heinemann, London, 1967). Badaczom snów już teraz udało się odsłonić tragiczny stan społeczeństwa, które wymagało aż demonstracji przeprowadzonej za pomocą komputerów i encefalografów, by uznać prosty fakt, że rozluźnienie świadomości racjonalnej i doświadczanie snów stanowi niezbędny dla zdrowia element życia. Wydaje się jednak, że owi badacze nie dostrzegają roli, jaką w przesłonieniu tego faktu odgrywa nauka ze swym wojującym intelektualizmem. Jest to ślepa plamka, która sprawi zapewne, że ich projekt badawczy, podobnie jak wszelka warta wydanych na nia pieniędzy działalność naukowa, zostanie wykorzystany w celach idiotycznych. Dla przykładu Herman Kahn i Anthony Wiener w swej książce The Year 2000 (Macmillan, New York, 1967) przedstawiają nam wizję „programowalnych snów”. To jedna z wielu egzemplifikacji działania technokratycznej zasady: nie pozwól, by to, co może zostać podrobione przez technologów, działo się naturalnie i niosło ludziom przyjemność. 
sterujemy, budując mosty i kariery? Toż to nieodpowiedzialne balansowanie na granicy psychicznej patologii. To wręcz atak na ludzi, wymierzony w sam rdzeń ich poczucia bezpieczeństwa, prowadzony za pomoca odmawiania prawdziwości wszystkiemu, co mają na myśli, wypowiadając najcenniejsze słowo ze swego słownika, słowo ,ja”. A przecież do tego właśnie zmierza kontrkultura, kiedy - podpierając się swymi tendencjami mistycznymi lub doświadczeniami narkotycznymi - atakuje realność ego jako izolowanej, czysto biologicznej (cerebral) jednostki tożsamości. W ten właśnie sposób, po raz kolejny, kontrkultura wykracza poza świadomość kultury dominującej, ryzykując przy tym, że zostanie uznana za bezczelne babranie się w perwersyjnych nonsensach.

Cóż jednak poza taką właśnie odważną (i, miejmy nadzieję, humanistycznie nacechowana) perwersją może stanowić radykalne, rzucone technokracji, wyzwanie? Jeżeli melancholijne dzieje rewolucji poprzedniego półwiecza nauczyły nas czegokolwiek, to daremności polityki skoncentrowanej wyłącznie na odrzucaniu kolejnych rządów, klas panujących tudzież systemów ekonomicznych. Taki model polityki skutkuje jedynie przeprojektowaniem umocnień i baszt technokratycznej fortecy. Zamiast tego należy poszukiwać fundamentów, na których ta cytadela stoi. A fundamenty owe leżą wśród ruin wizjonerskiej wyobraźni i poczucia międzyludzkiej wspólnoty. To właśnie dostrzegł Shelley już w najwcześniejszym okresie rewolucji przemysłowej, kiedy ogłosił, że w obronie poezji musimy przynosić światło i ogien ,,z tych odwiecznych krain, dokąd egoistyczna zdolność rozumu nie miałaby nigdy odwagi się wzbić”.

$$
* * *
$$

$\mathrm{Na}$ pierwszy rzut oka rozliczne odmiany młodzieżowego buntu moga wywołać wrażenie, że kontrkultura jest stanowczo mniej spójna, niż dotąd sugerowałem. Z jednej strony mamy przecież fantazyjną cyganerię bitników i hipisów, z drugiej - twardogłowy aktywizm polityczny studenckiej Nowej Lewicy. Czyż nie sa to w istocie dwie oddzielne i przeciwstawne sobie grupy: jedna (której początki rozwoju sięgają Ginsberga, Kerouaca i spółki) próbująca „wymiksować się” z uczestnictwa w życiu amerykańskiego społeczeństwa, druga (czerpiąca już z C. Wright Millsa i niedobitków tradycyjnej, socjalistycznej lewicy) dążąca do przeniknięcia w głąb i zrewolucjonizowania naszego życia politycznego?

\footnotetext{
8 Znakomity esej Shelleya Obrona poezji wciąż świetnie się broni jako manifest kontrkulturowy. Gdyby tylko nasi technicy, naukowcy i eksperci wszelkich dziedzin byli w stanie usłyszeć te potężnie brzmiące frazy! To musiałoby pomóc.
} 
Napięcie wyczuwalne pomiędzy owymi dwoma ruchami jest oczywiście rzeczywiste. Sądzę jednak, że na głębszym poziomie istnieje wspólny temat, motyw jednoczaç owe odmiany i tłumaczący zarazem fakt, iż hipisi i studenccy aktywiści wciąz widzą w sobie sprzymierzeńców. Z pewnością istnieje wspólny przeciwnik, w walce z którym łączą siły, lecz mamy również do czynienia z czynnikiem pozytywnym: podobną wrażliwością.

Zasadnicza jedność zróżnicowanych stylów kontestacji ukazuje się nam w niezwykłym indywidualizmie, który od zarania charakteryzuje aktywizm Nowej Lewicy. Identyfikujące się z Nową Lewicą organizacje w rodzaju SDS ${ }^{9}$ od zawsze protestowały przeciwko modnej tezie, że dotarliśmy w Wielkim Społeczeństwie ${ }^{10}$ do „kresu ideologii”" ${ }^{11}$. Pośród politycznie zaangażowanych kontestatorów panuje jednak poczucie, że ideologia jako taka stanowi pieśń przeszłości. Zasadnicza większość ugrupowań Nowej Lewicy nie dopuściła, by w ich politykierstwie (politicking) sztywna logika przesłoniła bądź wyparła nieredukowalny element ludzkiej wrażliwości. Tym, co odróżnia SDS - lub przynajmniej odróżniało we wczesnych latach - od starego typu radykalnych organizacji młodzieżowych (nadal reprezentowanych przez, dajmy na to, Progressive Labor Movement ${ }^{12}$ ), jest niechęć tych pierwszych do reifikacji doktryny do stopnia, w którym stałaby się bardziej istotna niż ciało i krew. W oczach większości przedstawicieli Nowej Lewicy żadna ideologia nie była nigdy wartościowa bądź przekonująca, o ile jednostki nie nadawały jej znaczenia własnymi działaniami:

\footnotetext{
9 Students for a Democratic Society (Studenci na rzecz społeczeństwa demokratycznego). Powstała w 1960 i działająca do 1969 roku polityczna organizacja studencka, będąca jednym z głównych wyrazicieli ideologii Nowej Lewicy (przyp. tłum.).

${ }^{10}$ Wielkie Społeczeństwo (Great Society) - zespół reform w polityce wewnętrznej, zapoczątkowanych przez prezydenta USA Lyndona B. Johnsona w 1964, mających na celu likwidację ubóstwa i niesprawiedliwości rasowej. Nowe programy ekonomiczne dotykały m.in. sfer edukacji, opieki zdrowotnej, problemów obszarów miejskich i komunikacji (przyp. tłum.).

${ }^{11}$ Teza ta jest, oczywiście, nieprawdziwa. Ideologia w warunkach technokracji wcale nie znika; staje się po prostu niewidzialna, wtapia się w ponoć niepodważalną prawdziwość światopoglądu naukowego. Dlatego właśnie technokraci zajmujący się „racjonalnościa”, „wydajnością” i „postępem” przemawiają w rzekomo wolnym od wartościowania języku statystyki i przekonują samych siebie, że nie cechuje ich żadna orientacja ideologiczna. Najskuteczniejszymi ideologiami są zawsze te, których granice pokrywają się z granicami świadomości, gdyż wówczas wywieraja wpływ na poziomie podświadomości.

${ }^{12}$ Progressive Labor Movement (właśc. Progressive Labor Party - Postępowa Partia Pracy) - założona w 1961 roku, działająca głównie w USA partia komunistyczna. W latach 60. XX wieku jej członkowie m.in. oskarżali ZSRR od zdradę ideałów komunizmu, rewizjonizm i tworzenie kapitalizmu państwowego, a także głosili konieczność walki bezpośrednio o komunizm, z pominięciem etapu gospodarki socjalistycznej (przyp. tłum.).
} 
tworzywem polityki jest osobiste zaangażowanie, nie abstrakcyjne idee. To właśnie było sednem obserwacji, jaką Staughton Lynd przedstawił na New University Conference w 1968 roku, gdy opłakiwał fakt, że nawet skłaniający się w stronę radykalizmu akademicy zbyt często „poza uniwersyteckimi kampusami nie stanowią modelowych przykładów osobiście zaangażowanego radykała". Wykładają marksizm lub socjalizm, lecz nie „spełniają swej powinności”.

Pierwszym obowiązkiem intelektualisty jest, jak powiada Noam Chomsky, „upierać się przy prawdzie”... To jednak, jakiego rodzaju prawdę odkryjemy, zależy od rodzaju życia, jakie wiedziemy... Mieć nadzieję, że jesteśmy w stanie ze zrozumieniem interpretować kwestie, w których nie mamy doświadczenia z pierwszej ręki, sprawy całkowicie niepotwierdzone biciem naszych $\operatorname{serc}^{13} \ldots$ oznacza tyle, co wykazywać się intelektualną pychą... Myślę, że czasy nie pozwalają nam już na zażywanie takiego luksusu i wymagaja, byśmy co najmniej wkroczyli na arenę, na której swoje robią partie polityczne, ludzie pracy i młodzież, próbujący rozjaśnić owo doświadczenie - stające się również naszym udziałem - głoszenia władzy prawd widzianych z perspektywy bojowników ${ }^{14}$.

Powyższe uwagi prowadza nas z powrotem do zaproponowanego przez R. D. Lainga rozróżnienia między „teorią” a „doświadczeniem”. Dla radykalnego intelektualisty, jak zresztą dla wszystkich, stwierdza Lynd, prawda musi mieć kontekst biograficzny, a nie tylko ideologiczny.

To właśnie ów indywidualistyczny styl doprowadził Nową Lewicę do ostatecznego rozpoznania w alienacji najważniejszego problemu politycznego chwili. Jednakże nie alienacji pojmowanej w sensie czysto instytucjonalnym, w którym kapitalizm (czy w zasadzie dowolna forma wysoko rozwiniętej gospodarki przemysłowej) doprowadza robotnika do wyobcowania od środków i owoców jego pracy, lecz raczej alienacji postrzeganej jako stępienie ludzkiej wrażliwości na innych, grożące przeniknięciem nawet w obszar tych rewolucyjnych wysiłków, które - motywowane intencjami jak najbardziej humanistycznymi - zmierzają do eliminacji zewnętrznych symptomów wyobcowania. Wszędzie, gdzie nie-ludzkie żywioły - czy będzie to rewolucyjna doktryna, czy pragnienie posiadania

\footnotetext{
${ }^{13}$ Unproved upon the pulses - John Keats, jeden z głównych przedstawicieli angielskiego romantyzmu, pisał w znanym liście z 3 maja 1818 r. do swojego przyjaciela, J. H. Reynoldsa: „[...] axioms in philosophy are not axioms until they are proved upon our pulses” (Aksjomaty filozofii nie są wcale aksjomatami, póki nie zostaną potwierdzone biciem naszych serc) (tłum. G. K.; przyp. tłum.).

${ }^{14}$ Wystapienie Lynda pojawia się w The New University Conference Newsletter, Chicago, 24 maja 1968, s. 5-6.
} 
dóbr materialnych - zyskują znaczenie większe od ludzkiego życia i pomyślności, mamy do czynienia z alienacją ludzi i otwarciem drogi, na której przekonane o własnej nieomylności jednostki moga wykorzystywać innych ludzi w charakterze zwykłych narzędzi (objects). W tym ujęciu rewolucyjny terroryzm okazuje się jedynie lustrzanym odbiciem kapitalistycznego wyzysku. Jak to ujęli francuscy studenci w jednym z wyrazistych haseł Maja 1968: „Une revolution qui demande que l'on se sacrifice pour elle est une revolution a la papa" (Rewolucja, która wymaga samopoświęcenia, jest rewolucją tatusiów).

Sens indywidualizmu Nowej Lewicy został przekonująco wyrażony w deklaracji oddziału SDS z Port Huron w 1962 roku:

Jesteśmy świadomi, że w celu uniknięcia prawienia komunałów musimy dokonać analizy konkretnych uwarunkowań porządku społecznego. Aby jednak taką analizę przeprowadzić, musimy oprzeć się na wskazaniach zasad podstawowych. Do naszych własnych, fundamentalnych wartości społecznych należą między innymi: koncepcja istoty ludzkiej, stosunków międzyludzkich i systemów społecznych. Jednostki uważamy za nieskończenie wartościowe oraz dysponujące niezrealizowanymi możliwościami umysłu, a także potencjałem doświadczania wolności i miłości... Przeciwstawiamy się depersonalizacji redukującej istoty ludzkie do poziomu rzeczy. Jeżeli brutalne koleje dwudziestego stulecia czegokolwiek nas nauczyły, to tego, że środki i cele pozostaja ze sobą w jak najściślejszym związku; tego także, że niejasne apele do „potomności” nie mogą usprawiedliwić okaleczającego charakteru współczesności...

Istniejący w dzisiejszym świecie olbrzymi dystans między człowiekiem a człowiekiem opisuja pojęcia takie jak samotność, wyobcowanie, izolacja. Owe dominujące tendencje nie moga zostać przezwyciężone za pomocą bardziej skutecznego zarządzania personelem ani coraz lepszymi gadżetami, lecz tylko przez miłość, która przeważy bałwochwalczy stosunek człowieka do rzeczy ${ }^{15}$.

Kwestia, do której odnoszą się tutaj studenci ze swym sentymentalnym szacunkiem do „miłości”, „samotności”, „depersonalizacji”, pozostaje w żywym kontraście wobec bardziej doktrynalnego stylu ich radykalnych poprzedników. Jeszcze pokolenie wcześniej, w czasie hiszpańskiej wojny domowej, Harry Pollitt, przywódca Brytyjskiej Partii Komunistycznej, był

${ }^{15}$ Cytowane w formie, w jakiej pojawia się w: Cohen M., Hale D., red. 1967. The New Student Left, Beacon Press, Boston, s. 12-13. 
w stanie z czystym sumieniem zalecić poecie Stephenowi Spenderowi, że powinien pojechać do Hiszpanii i dać się zabić: partia potrzebowała wszak większej ilości artystów-męczenników w celu poprawy i umocnienia własnego wizerunku. Na tym właśnie polega polityka ideologiczna na całkowitym podporządkowaniu osoby potędze partii i doktryny. Tego rodzaju wypaczenia nie charakteryzowały wyłącznie lewicy stalinowskiej. To przecież niezłomnie antystalinowski Sidney Hook, który w słynnej wymianie listów z Bertrandem Russellem, do której doszło na początku lat 50., posługując się logiką niczym siekiera, doszedł do wniosku, że powstrzymanie światowych ambicji Harry'ego Pollitta usprawiedliwiłoby uśmiercenie całego rodzaju ludzkiego ${ }^{16}$. Tego rodzaju bojowa postawa antystalinowska wymagałaby - chcąc nie chcąc - dwóch miliardów męczenników: nie można mieć watpliwości, że ów model politycznej postawy zdobyłby złoty medal w kategorii krwawego fanatyzmu. Gdyby bomba wodorowa była dostępna w szesnastym stuleciu, identycznej, mrożącej krew brawury moglibyśmy się spodziewać po Kalwinie i Loyoli... którzy nigdy nie żartowali... i być może dzisiaj po prostu by nas tutaj nie było.

To jednak jest dokładnie ten rodzaj zepsutych relacji międzyludzkich, od jakich odżegnuje się polityka Nowej Lewicy. Zamiast przedstawionego podejścia cechuje ją nad wyraz rozsądny lęk przed wywieraniem jakiegokolwiek nacisku na innych i przed zgoda na stosowanie przemocy w imię dowolnych ideałów, nieważne, jak bardzo ponętnych. Członkowie ruchu Nowej Lewicy sami robią, co do nich należy, nikt tam nie spłaca cudzych długów i nie zmusza innych do spłacania ich za siebie. Jak w niedawnym tekście zauważa Kenneth Keniston z Yale Medical School, „....manierą i stylem, ci młodzi radykałowie są bez reszty «indywidualistyczni», skupieni na relacjach twarzą w twarz, na bezpośrednich i otwartych stosunkach z innymi ludźmi; wrodzy natomiast wobec formalnie ustrukturalizowanych ról i tradycyjnych, biurokratycznych wzorców władzy i prawomocności”, - źródeł owej charakterystyki Keniston upatruje w modelu wychowania dzieci, powszechnym wśród współczesnej klasy średniej, modelu zakorzenionym tak mocno, że Keniston zastanawia się, czy ,jest w ogóle możliwe zachowanie otwartego i indywidualnego stylu, nie opartego na manipulacji, lecz na zaufaniu, przy jednoczesnej próbie budowy skutecznego programu na skalę ogólnokrajowa" ${ }^{\prime 17}$. Mamy tu do czynienia z problemem

${ }^{16}$ Dyskusja Russell-Hook pojawia się w: McClelland Ch., red. 1960. Nuclear Weapons, Missiles, and Future War, Chandler, San Francisco, s. 140-157.

${ }^{17}$ Por. Keniston K. 1968. Young Radicals, Harcourt, Brace \& World, New York. Studium zostało oparte na wnioskach Krajowej Komisji Nadzorującej kampanii „Vietnam Summer” 1967. 
realnym; ceną realizacji ideału „demokracji uczestniczącej” musi być organizacyjny bezwład. Z drugiej strony, być może miarą naszego społecznego zepsucia jest wiara w to, że demokracja jako taka może w ogóle być inna niż „uczestnicząca”.

Pisząc te słowa, mam jednak przykrą świadomość istnienia pośród kontestujących coraz bardziej wyraźnego ideologicznego dryfu w kierunku uznania stosowności uciekania się do słusznej przemocy, zauważalnego zwłaszcza wśród młodzieży poddanej wpływom ekstremistów spod znaku Black Power i tych, którzy wyznają romantyczną wizję walki partyzanckiej. Jest to szczególnie prawdziwe w odniesieniu do młodzieży europejskiej, gwałtownie wycofującej się na poziom stereotypowego pojęcia rewolucji. Niemniej w Stanach Zjednoczonych idee „polityki konfrontacji” i wiwaty, jakimi fetowana jest fikcja „wojny ludowej”, również zyskują na znaczeniu, w miarę narastania frustracji wywołanej brutalnością i kłamliwością działań establishmentu. Pośród radykałów pojawiają się - co tragiczne - coraz to kolejne próby znalezienia sposobu na „legitymizację morderstwa”, jak opisał to Camus, i wraz z tą tendencją Nowa Lewica naraża się na ryzyko utraty swego dotychczasowego ducha i szczerości. Wynika to z tego, że piękno Nowej Lewicy od zawsze polegało na zażartym dążeniu do nadania politycznej godności emocjom bardziej delikatnym, na gotowości do otwartej rozmowy o litości, miłości i rezygnacji z przemocy. Dlatego właśnie jest ze wszech miar smutne, gdy w imię owego nurzającego się w samozadowoleniu ducha walki duch humanistyczny ustępuje wiekowej tradycji polityki nienawiści, mściwości i napuszonego oburzenia. Rzecz nie w tym, że jest to po prostu ohydne, ale głupie. Miernikiem żarliwości przekonań staje się nagła gotowość, z jaką człowiek potrafi wdać się w bójkę z przypadkowo napotkanym policjantem.

Osobiście uważam, że ci, którzy ulegaja pokusie doktrynerskiej przemocy i sile jej manipulacji, wciąż pozostaja niewielką częścią rzesz kontestującej młodzieży - nie licząc krzykliwej mniejszości, która z oczywistych powodów zagarnia uwage prasy. Już choćby owa charakteryzująca Nowa Lewicę jakość niewykluczania nikogo - zgoda, by każdy mógł zająć własne stanowisko, nawet gdy wynika z niego całkowity bezsens - sprawia, że niemożliwe jest odtrącenie tych, którzy pojawiają się na manifestacjach z ikonami Che i przewodniczącego Mao oraz sloganami mrożącymi krew w żyłach. Niemniej głównym przesłaniem Nowej Lewicy pozostaje przesłanie wyrażone w motto SDS: ,Jeden człowiek, jedna dusza”. Sens tego hasła jest dostatecznie wyraźny: bez względu na koszta doktrynalne, należy zawsze mieć na uwadze wyjątkowość i godność jednostki oraz przyznać prymat wszystkiemu, co w danym momencie jest dla niej najbardziej istotne. 
Colin MacInnes, rozważając różnice pomiędzy młodymi radykałami z lat 30. i 60., zauważa, że dzisiejsza młodzież „wykazuje się większą osobistą odpowiedzialnością niż dawniej. Nie w sensie wypełniania «obowiązków» wobec państwa czy społeczeństwa, lecz wobec siebie samych. W większym stopniu przyglądają się sobie i własnym motywacjom"18. Każdy, kto spędził nieco więcej czasu wśród identyfikujących się z Nową Lewicą studentów, wie, o czym MacInnes mówi. Rzecz w trzeźwej introspekcji, porównywalnej do cechy zwanej przez Kościół katolicki „skrupulatnością” (scrupulosity). Przesiadywanie wśród tych młodych ludzi podczas ich pogłębionych, do przesady drobiazgowych sesji, kiedy to „zagłębiają się we własne ja" w celu odkrycia rzeczywistych motywacji, może być doświadczeniem trudnym do zniesienia, podobnie jak obserwacja ich uporczywego poszukiwania „bezpośredniości” wolnej od organizacyjnych i hierarchicznych dystynkcji. Niemniej jest to - w najgorszym wypadku - przesadna dbałość o zachowanie cnoty, która każe młodzieży uparcie utrzymywać, że ani teoria, ani retoryka nie mogą przeważyć nad naszymi konkretnymi, wpływającymi na nas i bliźnich poczynaniami oraz że ostateczną instancją musi pozostać osoba, nie doktryna.

Powstaje w tym punkcie pytanie: czym jest osoba? Czym, w swej najgłębszej istocie, jest owo ulotne i często chaotyczne ludzkie coś, co stanowi podstawę systemów społecznych i ideologii i co musi się stać moralnym punktem odniesienia współczesności? Ledwie zdażzymy zapytać, a już polityka społeczna oddaje pola temu, co Timothy Leary określił mianem „polityki układu nerwowego". Świadomość klasowa jako zasada twórcza ustępuje tutaj... świadomości świadomościowej. W tym właśnie miejscu Nowa Lewica i bitnikowsko-hipisowska cyganeria podają sobie ręce. Albowiem nawet $\mathrm{w}$ najbardziej wrogiej karykaturze artystowskie peryferia naszej młodzieżowej kultury ukazują swą odmienność i wyrazistość. Podstawa jest tu intensywny namysł nad własnym ja, nad niewidocznym na powierzchni bogactwem jednostkowej świadomości. Stereotypowy bitnik czy hipis, skupiony na sobie samym, oderwany od reszty społeczeństwa w narkotycznym śnie czy ekstatycznej kontemplacji... Co kryje się pod tymi popularnymi obrazami niekiedy pociesznego, a czasami beznadziejnie błądzącego poszukiwania prawdy o sobie samym?

Bitnikowsko-hipisowska bohema może się jawić jako zbyt oddalona od społecznego zaangażowania radykałów Nowej Lewicy, lecz owo

\footnotetext{
${ }^{18}$ Maclnnes C. 1967. Old Youth and Young, „Encounter” wrzesień 1967. Inne omówienie tego tematu, w którym natykamy się na ten sam moment - zob. sympozjum Confrontation. The Old Left and the New, „The American Scholar” jesień 1967, s. 567-89.
} 
wycofanie następuje w kierunku świetnie rozumianym przez politycznych aktywistów. „Odlatujemy” wszak w głąb, w stronę głębszych pokładów samowiedzy. Swobodę przejścia z jednego skrzydła kontrkultury do drugiego dostrzec można w schemacie, jaki widzimy w rozwoju wielu z wolnych uniwersytetów.

Te kontestatorskie akademie zakładane sa zazwyczaj przez przedstawicieli kampusowej Nowej Lewicy i początkowo kłada nacisk na politykę o dużym ciężarze gatunkowym. Stopniowo jednak ich programy nauczania stają się coraz bardziej „hip” zarówno pod względem treści, jak i metod dydaktycznych: psychodelia, pokazy świetlne, multimedia, teatr totalny, McLuhan, egzotyczne religie, dotyk i czułość, ekstatyczne laboratoria... ${ }^{19}$. Takie samo przejście prześledzić możemy w karierze Boba Dylana, który cieszy się szacunkiem wśród przedstawicieli wszystkich odmian młodzieżowych kultur kontestacji. Wczesne piosenki Dylana były tradycyjnymi, folkowymi protest-songami, wykładającymi oczywiste kwestie sprawiedliwości społecznej; wyrażały sprzeciw wobec szefów, wojny i wyzysku człowieka przez człowieka.

Potem, znienacka, właściwie jakby Dylan doszedł do wniosku, że tradycyjnymi balladami w stylu Woody'ego Guthriego nie sięgnie dostatecznie głęboko, utwory artysty nasiąkają surrealizmem i psychodelią. Dylan znajduje się naraz gdzieś pomiędzy racjonalizującym umysłem (cerebrum) społecznego dyskursu, badaniem rzeczywistości sennych koszmarów oraz próbami odsłonięcia splątanych podstaw ludzkich zachowań i opinii. $\mathrm{Na}$ tym etapie, z początkiem lat 50., projekt podjęty przez bitników - zadanie rekonstrukcji własnego życia, modeli percepcji i wrażliwości - zaczyna raptownie usuwać w cień społeczne zadanie zmiany instytucji i zasad.

Możemy zatem wśród środowisk młodzieżowych zaobserwować całe spektrum myśli i doświadczenia, łączące ze sobą nowolewicową socjologię Millsa, freudowską odmianę marksizmu reprezentowana przez Herberta Marcusego, anarchizm oraz terapię gestalt Paula Goodmana; apokaliptyczny mistycyzm ciała Normana Browna, opartą na myśli zen psychoterapię Alana Wattsa i wreszcie hermetycznie tajemniczy narcyzm Timothy'ego Leary'ego, kontinuum, w którym świat wraz ze swymi troskami może się ostatecznie skurczyć do rozmiarów drobiny pyłu wirującego w prywatnej, psychodelicznej otchłani jednostki. Posuwając się wzdłuż owego spektrum, widzimy, jak socjologia ustępuje stopniowo psychologii, polityczny kolektywizm oddaje pola osobie, a zachowania świadome i klarownie uzasadnione wycofują się pod naporem sił pozarozumowej głębi.

${ }^{19}$ Por. Keyes R. 1967. The Free Universities, „The Nation” 2 października 1967. 
Ekstrema owego spektrum początkowo zdają się, co prawda, zupełnie ze sobą niespowinowacone, lecz nie powinniśmy się dziwić, gdy na tym samym panelu dyskusyjnym spotkamy wszystkie wymienione wyżej osoby. Londyński Kongres Dialektyki Wyzwolenia, zorganizowany latem 1967 roku, był właśnie tego typu wydarzeniem: próbą wypracowania priorytetów prowadzących do psychicznego i społecznego wyzwolenia wśród uczestników rekrutujących się zarówno z rewolucyjnych kręgów Nowej Lewicy, jak i spośród egzystencjalnych psychiatrów. Pojawił się również Allen Ginsberg - który co prawda nie przemówił, za to zaintonował pieśń Hare Kriszna. Czego można się było spodziewać, żadnych priorytetów nie ustalono. Co równie istotne, na kongresie nie zdołano nawiązać żadnych znormalizowanych stosunków z rzecznikami ruchu Black Power, takimi jak Stokely Carmichael, dla którego - co tragiczne, acz zrozumiałe - prawdziwa społeczna siła, wbrew wszystkiemu, czego nauczyła nas historia, ponownie wydaje się opierać na lufach karabinów.

Pomimo tych problemów poczucie wspólnoty sprawy było tam niewatpliwie obecne: nacisk kładziono na konieczność rewolucyjnej zmiany, która w identycznym stopniu musi objąć zarówno psyche, jak i społeczeństwo. Nawet dla aktywistów Black Power głównym źródłem uzasadnienia walki są prace egzystencjalistycznych teoretyków, na przykład Frantza Fanona, którzy największej wartości czynnego buntu upatrują w psychicznym wyzwoleniu uciemiężonych ${ }^{20}$.

Dlatego właśnie gdy ugrupowania Nowej Lewicy organizują demonstracje, z pewnością pojawią się na nich i odurzeni hipisi. Być może zignoruja po prostu ciężkawe, polityczne przemowy i zajmą się „wodowaniem żółtej łodzi podwodnej" "21 bądź odprawią egzorcyzmy nad Pentagonem. W Berkeley, po incydentach roku 1966, Nowa Lewica i miejscowi hipisi

${ }^{20}$ Ruch Black Power bywa również wciagany w obszar kontrkultury na inne sposoby. W książce Eldridge'a Cleavera Soul on Ice (McGraw-Hill, New York, 1968) znajdujemy zajmująca analizę ukrytych, seksualnych podwalin rasizmu. Por. esej The Great Mitosis. Analiza sugeruje jednak, że podobnie jak niektórzy reprezentanci Nowej Lewicy, Cleaver uważa walkę o emancypację za dziedzinę męskich mężczyzn, którzy muszą dowieść własnej przydatności poprzez „narażanie własnych jaj”. Zbyt często sugeruje się tam, iż samica powinna się zadowolić rolą opiekunki domowego ogniska, rozpalonego dla jej poranionego w bitwach obrońcy, lub dołączyć do bojowników w charakterze markietanki. W obu wypadkach wspólnota zostaje ocalona dla niej, zamiast również przez nią. Oznacza to, jak sądzę, że krzywdzące stereotypy płciowe zakorzenione są na głębszym poziomie świadomości niż uprzedzenia rasowe. Komentarze w tej kwestii por. Roszak B. 1966. Sex and Caste, „Liberation” grudzień 1966, s. 28-31.

${ }^{21}$ „Żółta łódź podwodna” - chodzi naturalnie o odwołanie do jednego ze sztandarowych utworów ery psychodelii, piosenki Beatlesów Yellow Submarine (przyp. tłum). 
bez najmniejszego kłopotu zorganizowali wspólnie happening Human Be-In, celebrujący quasi-zwycięstwo studentów nad administracją. Wskutek licznego udziału hipisów święto dość szybko przybrało charakter masowego „festiwalu miłości”, lecz nikt nie uznał tego za niestosowne. Prawdopodobnie najbardziej istotnym rysem wydarzenia był fakt, że pośród czterdziestu tysięcy uczestników znalazło się wielu nastolatków z okolicznych gimnazjów i liceów - tak zwanych „małolatów” (teeny-boppers), którzy stanowią obecnie większość tłumu przelewającego się przez Telegraph Avenue w Berkeley. Dla tych młodzików kolejna fala kontrkultury, rozróżnienia między buntowniczym aktywizmem i artystowską bohemą, stają się stopniowo coraz mniej wyraźne. Bez wątpienia - czego obawiają się włodarze tamtejszych miast - małoletnia młodzież nabywa na tej alei licznych złych nawyków - z tym że źródłem zepsucia są zapewne w takim samym stopniu ulotki SDS, jak psychodeliczne gazety, i nie ma większej świadomości różnicy pomiędzy rzuceniem studiów a zajęciem mocnych pozycji w oczekiwaniu na polityczną konfrontację. Dla nich wszystko sprowadza się do kontestacji - a wszelkie bardziej szczegółowe kategorie mają znaczenie drugorzędne.

Fundamentalną jedność spajająca różnorodne odłamy kontrkultury możemy zatem dostrzec, jeżeli spojrzymy na działania bitnikowsko-hipisowskiej bohemy jak na wysiłek mający na celu wypracowanie struktury osobowości i stylu życia, zakorzeniony w nowolewicowej krytyce społecznej. Przedstawiciele owej młodej cyganerii sa, w swym najlepszym wydaniu, utopijnymi pionierami świata leżącego poza intelektualnym odrzuceniem programu Wielkiego Społeczeństwa (Great Society). Staraja się wypracować kulturową bazę dla polityki Nowej Lewicy, odkryć nowe modele wspólnoty i rodziny, nową obyczajowość seksualna, nowe sposoby na utrzymanie się, nowe formy estetyczne, nową tożsamość jednostki i wszystkiego tego upatruja na przeciwległym brzegu polityki opartej na sile, mieszczańskim domu i konsumpcyjnym społeczeństwie. Kiedy Nowa Lewica nawołuje do pokoju, przedstawiając nam ponura analizę rzeczywistej sytuacji w Wietnamie, hipisi natychmiast przekładają to słowo na śanti - „pokój, który przekracza nasze pojmowanie” - wypełniając tym samym duchowy wymiar ideału. Badanie sposobu życia zgodnego z pojęciem śanti ma może niewiele wspólnego z działaniami na rzecz zakończenia wojny wietnamskiej, lecz stanowi być może najlepszą metodę zapobieżenia kilku kolejnym Wietnamom. Owszem, eksperymenty, jakie znajdujemy na hipisowskiej rubieży kontrkultury, wciąż są jeszcze w powijakach, a często wręcz poronione. Musimy jednak pamiętać, że młodzi eksperymentatorzy pojawili się wśród nas najdalej kilkanaście lat temu i że przedzieraja 
się przez grube warstwy zwyczajów i instytucji, które na okrzepnięcie i budowę fortyfikacji miały lat kilkaset. Krytyka tych eksperymentów jest uprawniona i konieczna, jednak rozpaczliwe załamywanie rąk nad tym, co znajduje się jeszcze w powijakach, wydaje się stanowczo przedwczesne.

$$
* * *
$$

Właśnie dlatego, że polityka Nowej Lewicy pozostaje w związku z całością kultury kontestacji, możliwość jakiegokolwiek trwałego sojuszu z najbardziej nawet wykluczonymi reprezentantami pokolenia dorosłych jest poważnie ograniczona. Dopóki młodzi będą akcentować w swej polityce konieczność dalszej integracji osób ubogich i pokrzywdzonych przez los ze sferą technokratycznego dobrobytu, dopóty będą mogli cieszyć się z nawiązywanych ad hoc związków z robotnikami i ich związkami zawodowymi, a także z uciskanymi mniejszościami. Tego rodzaju alianse nie maja jednak szans doprowadzić do trwałego zjednoczenia. Kiedy ciśnienie rosnące w czarnych gettach naszych miast spowoduje wreszcie wybuch, rebelia może sprawiać wrażenie prologu rewolucji. Zbuntowani młodzi wygłoszą wówczas słowa współczucia i udzielanego powstańcom wsparcia, w takiej oczywiście mierze, w jakiej ruch Black Power dopuści do udziału białych sprzymierzeńców ${ }^{22}$. Niebawem jednak, bez względu na początkowe zamiary czarnej partyzantki, głównym zajęciem buntowników staną się masowe rabunki - będące sposobem ubogich na wdarcie się na obszar społeczeństwa konsumpcyjnego. I pod tym właśnie względem gniewna, rozbrzmiewająca w gettach agitacja brzmi niczym wołanie tłumu u wrót technokracji - my chcemy do środka.

O ile Skonyt Allena Ginsberga jawi się jako fundujacy dokument kontrkultury, o tyle pamiętać należy o tym, co poeta miał do powiedzenia światu: „Wszystkie swoje pieniądze spaliłem w koszu na śmieci”. Czy będzie zatem zwycięstwem, czy może porażką kontrkultury, kiedy czarny człowiek wywalczy sobie wreszcie, za pomocą rozpaczliwych środków doraźnych, wolność i ostatecznie wymoże na Wielkim Społeczeństwie dostęp do „białej” wersji rabowania sklepów: stabilne zatrudnienie, bezpieczny dochód, łatwość zaciagania kredytów, swobodny dostęp do okolicznych centrów handlowych i własny dom, w którym będzie mógł gromadzić sterty pakunków

\footnotetext{
${ }^{22}$ Oto, dla przykładu, tekst ulotki rozdawanej w nowojorskim Harlemie przez „Komitet Zatroskanych Białasów”: „Będziemy omawiać rozpieprzenie oddziałów specjalnych policji (tudzież gwardii narodowej bądź wojska), jakie ma nastapić w razie dowolnego powstania czarnych na obszarze Nowego Jorku. Będziemy również omawiać blokadę zaplanowanych na jesień szkoleń gwardii narodowej w zakresie «kontroli tłumu» i inne tematy".
} 
z zakupami? Jest to sprawa kluczowa, gdyż odsłania problem, z jakim mierzy się kontrkultura, stająca przed niewątpliwie palącymi pytaniami związanymi ze sprawiedliwością społeczną. Czym bowiem jest sprawiedliwość społeczna w odczuciu społecznie pokrzywdzonych i wywłaszczonych? W jawnie oczywisty sposób oznacza ona uzyskanie dostępu do wszystkiego, z czego wykluczył ich egoizm klasy średniej. W jaki jednak sposób można taki dostęp zyskać, nie stając się zarazem integralnym, wspierającym elementem technokracji? Co może uczynić ruch Black Power, czarna kultura, czarna świadomość, by nie odegrać roli etapu przejściowego na drodze do czarnej komercji, czarnego konformizmu, czarnego dobrobytu: wreszcie do współczesnej Ameryki klasy średniej, tyle że zaludnionej przez ludzi odmiennej barwy skóry? Rozwiązanie tego dylematu wymaga niezwykle skrupulatnego podejścia, taktu i wrażliwości - cech, których niedostatek stanowi częsta przypadłość w środowiskach osób społecznie poszkodowanych, zaangażowanych w zażartą walkę polityczna.

Rozważmy dla przykładu sytuację, z jaką przyszło się mierzyć francuskim studentom w maju 1968, podczas strajku generalnego. Naczelnym ideałem chwili było wywalczenie ,pracowniczej kontroli” nad francuskim przemysłem. Znakomicie; czy jednak pracownicze ciała zarządzające byłyby odporne na niebezpieczeństwo technokratycznej integracji? Niestety nie. Nietrudno jest bowiem wyobrazić sobie technokrację odradzającą się na wyższych szczeblach rad robotniczych powoływanych przez sklepikarzy i robotników - a być może nawet wykorzystującą te nowe, pozbawiające złudzeń i ciężkie realia ku swojej niemałej korzyści! Probierzem kwestii byłoby pytanie: w jakim stopniu robotnicy sa gotowi do likwidacji całych sektorów gospodarki, jeżeli okazałoby się to konieczne do realizacji celów odmiennych od zwiększenia wydajności produkcji i poziomu spożycia wytworzonych dóbr? W jakiej mierze byliby gotowi odsunąć na bok technokratyczne priorytety na rzecz nowej prostoty, spowolnienia tempa społecznego życia i uzyskania niezbędnej ilości wolnego czasu? Dobrze by było, gdyby zwolennicy pracowniczej kontroli poddali te kwestie poważnemu namysłowi. Załóżmy bowiem, że francuscy robotnicy rzeczywiście przejmują moc decyzyjna nad gospodarką - który to cel stracił zresztą wiele ze swego wcześniejszego powabu, gdy tylko rząd de Gaulle'a zaproponował nowe rozwiązania płacowe. Czy monterzy z zakładów Renault rozważyliby likwidację własnych miejsc pracy ze względu na to, że samochody i zagęszczający się ruch uliczny są raczej plagą niż udogodnieniem? Czy pracownicy z zakładów samolotowych przerobiliby Concorde’a na żyletki z powodu twierdzeń, że ów cud techniki lotniczej pod względem społecznym z pewnością okaże się wynalazkiem straszliwym? Czy robotnicy 
zatrudnieni we francuskich zakładach zbrojeniowych wykazaliby się gotowościa do zakończenia produkcji force de frappe $e^{23}$, uznając że zaprowadzenie równowagi strachu należy do najbardziej nikczemnych występków technokracji? Podejrzewam, że odpowiedź na wszystkie powyższe pytania brzmiałaby „nie”. Zmianie uległby skład społeczny technokracji, lecz owa zmiana nie oznaczałaby w istocie niczego ponad poszerzenie fundamentu, na którym spoczywają imperatywy leżące u podłoża technokracji.

Zawsze ilekroć relacje kontrkulturowej młodzieży i wyklętego ludu ziemi $^{24}$ wykraczaja poza problem integracji, powstaje poczucie dojmujacej niezręczności. Wartości kulturowe niezadowolonej młodzieży muszą wydawać się dziwactwem ludziom, których uwagę w zrozumiały sposób przykuwa kwestia wywalczenia dostępu do kuszących dóbr konsumpcyjnych, jakimi cieszy się klasa średnia ${ }^{25}$. Jakże zdumieni muszą być ci, którzy od tak dawna cierpieli i żyli w biedzie, odkrywając, że dzieci nowobogackich ubierają się w szmaty, przeobrażają swoje „chaty” w coś ledwie odróżnialnego od mieszkania w slumsach i przesiadują na ulicach jak żebracy. I - odwrotnie - jakie znaczenie może mieć najnowszy, surrealistyczny album Beatlesów dla bezrobotnego górnika czy harującego na farmie imigranta? Co mają kloszardzi z Nanterre sądzić o ostatniej, pokazanej na Lewym Brzegu produkcji Arrabala? Pewne jest, że nie postrzegają owych dziwnych zjawisk jako elementu własnej kultury, lecz jako nieco szalone ciekawostki, którymi zabawia się zepsuta młodzież z klasy średniej. Być może, identycznie jak marksistowscy strażnicy sprawiedliwości społecznej,

${ }^{23}$ Force de frappe (fr. siła uderzeniowa) - ogólne określenie francuskiej broni atomowej, pojmowanej jako element systemu odstraszania nuklearnego (przyp. tłum).

${ }^{24}$ Wyklety lud Ziemi (Les Damnés de la terre) - tytuł wydanej w 1961 roku książki Frantza Fanona, czarnoskórego francuskiego psychiatry, filozofa, autora cennych badań dotyczących procesów dekolonizacyjnych. W Wykletym ludz̨ie Ziemi Fanon analizuje rolę klasy, rasy, kultury i przemocy w walce o niepodległość narodowa.

${ }^{25}$ Por. Daniel i Gabriel Cohn-Bendit: „Różnice pomiędzy rewolucyjnie nastawionymi studentami a robotnikami wyrastają bezpośrednio z różnic ich pozycji społecznej. Jako że niewielu studentów doświadczyło prawdziwie dotkliwego ubóstwa, ich walka dotyczy samej hierarchicznej struktury społeczeństwa, ucisku stosowanego również w warunkach dobrobytu. Nie tyle muszą się oni mierzyć z niedostatkiem dóbr materialnych, co z własnymi niespełnionymi pragnieniami i aspiracjami. Robotnicy, z drugiej strony, cierpią wskutek ucisku bezpośrednio ekonomicznego - zarabiają poniżej 500 franków miesięcznie, pracując w słabo wentylowanych, brudnych i hałaśliwych fabrykach, gdzie panoszą się brygadziści, główni inżynierowie i dyrektorzy, spiskujący w celu utrzymania podwładnych na dotychczasowych miejscach", Obsolete Communism. The Left-Wing Alternative, s. 107. Cohn-Bendit twierdzi jednak, iż wbrew owym radykalnie odmiennym horyzontom politycznym możliwa jest między obiema grupami wspólnota sprawy, oparta na jego taktyce „spontanicznego oporu" na ulicach. 
widzą w nich nawet nieznośne manifestacje „dekadencji” - neurotycznego niezadowolenia tych, którzy nie potrafią z wdzięcznością zająć się spokojną realizacją obowiązków, nakładanych przez życie w rozwiniętym społeczeństwie przemysłowym.

Problem, z jakim boryka się kontrkultura w relacjach ze sferami społecznie wykluczonych, powraca na innym poziomie - co zakrawa na dość bolesną ironię - w dwójnasób. Jak już wspominaliśmy, to właśnie kulturowe eksperymenty młodych narażone są na największe ryzyko zainfekowania duchem komercji - i wskutek jego działania, na utratę mocy buntowniczego przekazu. To właśnie owe eksperymenty na niwie kultury przyciagaja zainteresowanie odurzających się nimi hulaków z klasy średniej, którzy tworzą bastion technokratycznego porządku. I jest to zainteresowanie niezdrowe. Ludzie, o jakich mówimy, odwiedzają dzielnice cyganerii, by popatrzeć na „dzieci kwiaty”, wpadają do klubów z muzyką rockowa, wykładają minimalną cenę 5 dolarów po to, by zabawić się w podglądacza na projekcji Le Cimetière des Voitures - wszystkie te rozrywki stały się współczesna, coraz bardziej popularną wśród zamożnych, wersją slumming ${ }^{26}$ : przelotnym flirtem z kontestacją, flirtem nieuchronnie zniekształcającym pierwotne, prawdziwe oblicze zjawiska.

Nie wolno lekceważyć tendencji grożącej kontrkulturze neutralizacja siły oporu ze strony tego rodzaju fałszywego zainteresowania. Buntownicy powinni mieć się na baczności i wykazywać najwyższa przezornością, by nie trafić w charakterze eksponatów do komercyjnego gabinetu osobliwości - niczym egzemplarze egzotycznej fauny, przeniesione żywcem z ostępów dzikiej dżungli... przez „Time’a”, „Esquire’a” tudzież Davida Susskinda. Na tak zdradzieckim gruncie ryzyko postawienia złego kroku, przeliczenia się, jest wprost olbrzymie. Bob Dylan, opłakując bezmiar zepsucia naszej epoki, osłabia swoją wiarygodność, wydając rok po roku w wytwórni Columbia płytę za milion dolarów - która ma większe szanse trafić na półkę pod nowoczesnym, stereofonicznym sprzętem z radiem i gramofonem w połyskującej, mahoniowej obudowie niż do zamieszkanego przez przedstawicieli bohemy poddasza. Vanessa Redgrave - weteranka Komitetu $100^{27}$ i prowadzonych przez jego członków strajków okupacyjnych w Whitehall, zakładająca na siebie fidelowskie mundury polowe

${ }^{26}$ Slumming - slum tourism - turystyka slumsowa - praktyka odwiedzania biednych, ubogich dzielnic miast w celu osobistego przyjrzenia się życiu ich mieszkańców. Ze slummingiem mamy do czynienia od lat 80. XIX stulecia. Ów rodzaj rozrywki początkowo dotyczył przede wszystkim Londynu i Nowego Jorku.

${ }^{27}$ Komitet 100 (The Committee of 100 ) - brytyjskie ugrupowanie antywojenne, założone w 1960 przez setkę sygnatariuszy, wśród których znalazł się m.in. Bertrand Russell. 
i wyśpiewująca na Trafalgar Square kubańskie ballady rewolucyjne, użycza zarazem swych talentów filmom playboyowskiej proweniencji w rodzaju Powiekszenia. Nawet Herbert Marcuse, zreszta ku swemu wielkiemu rozgoryczeniu, po niemiecko-francuskim buncie studentów z 1968 roku stał się ulubieńcem mediów w całej Europie i Ameryce. „Bardzo mnie to niepokoi - komentował ową sytuację Marcuse. - A jednocześnie ten fakt stanowi piękne potwierdzenie mojej filozofii, głoszącej, że w obecnym społeczeństwie wszystko może zostać wchłonięte, wszystko może ulec strawieniu" 28 .

Od takiego zaciemnienia prawdziwego kontestatorskiego talentu niedaleko już do punktu, w którym całość kontrkultury przejęta zostanie przez cynicznych lub oszukujących samych siebie oportunistów, którzy staną się - lub łaskawie pozwolą się mianować - rzecznikami młodzieńczego buntu. Dlatego właśnie widzimy teraz projektantów ubrań, fryzjerów, redaktorów magazynów mody oraz prawdziwa plejadę gwiazd pop, którzy - nie mając w głowach ani jednej myśli, której nie umieściłby tam spec od PR - zaczynają znienacka wyłuszczać „,filozofię dzisiejszej zbuntowanej młodzieży", co chętnie publikują niedzielne dodatki dzienników... między tekstem o luksusowej bieliźnie a wydrukowanym w pełnym kolorze raportem z niedawno odkrytej egzotycznej plaży dla nudystów, na której warto spędzić najwspanialsze wakacje życia. W tej sytuacji, nie bez powodu, projekt kontrkultury zaczyna się wydawać przeprowadzoną na ogólnoświatową skalę akcją medialną.

Łatwo jest stracić nadzieję na to, że ów ruch uniknie obu tych niebezpieczeństw: z jednej strony słabości kulturowych związków z uciskanymi społecznie klasami; z drugiej podatności na wykorzystanie przez rozbawioną socjetę w charakterze zabawnego numeru cyrkowego.

$$
* * *
$$

Przebycie tego socjopolitycznego toru przeszkód stanowi dla kontrkultury zadanie bez wątpienia wymagające, którego realizacja może zając nawet większą część życia następnego pokolenia. Przezwyciężenie komer-

Zwolennicy komitetu stosowali wolne od przemocy metody walki o realizację swych celów, takie jak np. nieposłuszeństwo obywatelskie.

${ }^{28}$ Marcuse, Varieties of Humanism, „Center Magazine” (Center for the Study of Democratic Institutions, Santa Barbara), czerwiec 1968, s. 14. Z drugiej strony, na innym poziomie społecznym, Marcusego trapiły bardziej palące sprawy. Padające ze strony miejscowego Ku Klux Klanu groźby pozbawienia życia zmusiły go do opuszczenia domu w San Diego w lipcu 1968. Ów incydent przypomina nam o istnieniu mrocznych bastionów technokracji (w rodzaju południowej Kalifornii), w których wciąż egzystują troglodyci. 
cjalizujących i trywializujących sztuczek społeczeństwa technokratycznego będzie wymagało wytrwania do momentu, gdy zniknie atmosfera nowości, która otacza teraz kulturę młodzieżową i sprawia, że łatwo przypisuje się jej etykietkę przelotnej mody. W trakcie tego procesu będzie musiało dojrzeć to, co często jest dla młodzieży raczej skłonnością do bystrego wnioskowania i instynktem, czyli to, co musi stać się racjonalną treścią dorosłego życia. Jeżeli kontrkultura uwięźnie w barwnym grzęzawisku nieprzeanalizowanej symboliki, gestów, mód odzieżowych i sloganów, to nie zapewni niczego, z czego mogłoby wyrosnąć długotrwałe zaangażowanie $-\mathrm{z}$ wyjątkiem, żałosnym zreszta, tych ludzi, którzy potrafią pogodzić się z rolą starzejących się wiecznych studentów, podtatusiałych bywalców rockowych klubów i hipisowskich zlotów. Skończy jako chwilowy styl, bezustannie porzucany i pozostawiany następnej fali dojrzewających akurat nastolatków: pełen nadziei początek, który nigdy nie stanie się niczym więcej niż właśnie początkiem. Co do zadania włączenia w nurt kontrkultury społecznie uciśnionych mniejszości: podejrzewam, że będzie ono musiało poczekać do momentu, w którym - naturalną koleją rzeczy - nastąpi czarna rewolucja. Wtedy to nowa, ciemnoskóra klasa średnia wychowa własną zbuntowaną młodzież, która - w roli spadkobierców wszystkiego, co ich rodzice uznali za warte podjęcia walki - rozpocznie, na podobieństwo swych białych partnerów, walkę o wyzwolenie z technokratycznej pułapki.

Poza jednak problemami stwarzanymi przez ten typ społecznej manipulacji spotykamy się z projektem o jeszcze bardziej krytycznym znaczeniu: projektem zdefiniowania etycznej godności kulturowego ruchu, stojącego w radykalnej niezgodzie ze światopoglądem naukowym. Ów projekt jest tak doniosły, ponieważ musi wreszcie paść odpowiedź na wyzwanie rzucane przez licznych zaniepokojonych intelektualistów, obawiających się, że kontrkultura nadejdzie nie w obłoku chwały, lecz niosąc na sztandarze znak bestii. Gdy tylko ktoś zaczyna opowiadać o wyzwoleniu pozarozumowego potencjału osobowości, wielu innych widzi przed soba perspektywę przerażającą: wizję pełnego sprzeczności szaleństwa, które grozi nowym rodzajem barbarzyństwa. Ci zatroskani ludzie nie bez powodu tak pospiesznie wznosza barykady w obronie rozumu. Oto, dla przykładu, Philip Toynbee przypomina nam o „dawnej nihilistycznej tęsknocie do obłędu, rozpaczy i totalnego odrzucenia wszystkiego", która stała się filarem faszyzmu:

...ważnym jest pamiętać, iż Himmler był pośród nich wszystkich nihilistą najprawdziwszym. Ważnym jest, by pamiętać, że najskuteczniejszymi formami obrony przeciwko powrotowi faszyzmu do Europy sa: 
nadzieja, przyzwoitość i racjonalność. Świadomość tych kwestii powinna zostać wpojona, o ile to możliwe, tym wszystkim młodym ludziom, którzy określają się mianem lewicowych, lecz którzy uwielbiają igrać nihilistycznymi zabawkami na niwie sztuki i dyskursu. Ostatecznym zawołaniem faszyzmu wciąż pozostaje hasło Millana Astraya „Viva, viva la Muerte" ${ }^{\prime 2}$.

Ta krytyka jest oburzająco wręcz niesprawiedliwa. Hasło „Make love not war" nadal widnieje na sztandarze, pod którym gromadzi się znakomita większość młodych kontestatorów, a ci, którzy nie są w stanie dostrzec różnicy pomiędzy tego rodzaju sentymentem a hasłami Hitlerjugend, wykazuja się moralnym zaślepieniem. Na podobnej zasadzie jednym z najbardziej znamiennych aspektów kontrkultury jest kultywacja pośród kontestujących mężczyzn kobiecej wrażliwości. Stanowi ona, naturalnie, doskonały cel niekończącej się krytyki, lecz ów styl jest w oczywisty sposób przemyślanym zabiegiem młodzieży, mającym na celu podcięcie gałęzi prymitywnego i prostackiego męskiego szowinizmu (be-manliness), charakteryzującego amerykańskie życie polityczne. Dobrze by było, gdybyśmy uszanowali ten typ łagodnego erotyzmu, póki jest nam dostępny, miast go wyśmiewać. A jednak... na obrzeżach kontrkultury rodzą się również zjawiska niepokojące. Raz po raz, w sztuce i teatrze naszej młodzieży pojawiaja się elementy pornograficznej groteski i mrożącego krew w żyłach sadomasochizmu, wkraczając bez przerwy na łamy podziemnej prasy. Liczne periodyki zdają się funkcjonować w oparciu o założenie, że szczera rozmowa na dowolny temat oznacza rozmowę prowadzoną językiem prymitywnym i dzikim. Pozornie libertariański erotyzm tego stylu zdradza kompletny brak świadomości, że profesjonalna pornografia karmi się lubieżną seksualnością klasy średniej i jest gruntownie zainteresowana utrzymaniem przekonania, że seks jest czymś występnym. Tym, czym prohibicja stała

${ }^{29}$ Toynbee recenzujący niedawne studia nad faszyzmem w „The Observer” (London), 28 lipca 1968. W podobnym duchu brytyjski dramaturg Arnold Wesker określił hipisów „uroczymi, małymi faszystami”, a krytyk społeczny Henry Anderson przemianował Ligę na rzecz Wolności Seksualnej na Ligę Seksualnego Faszyzmu. Cięższą gatunkowo prezentację owych lęków znajdujemy w eseju Davida Holbrooka R. D. Laing and the Death Circuit, „Encounter" sierpień 1968. Z kolei praca Petera Vierecka Metapolitics. The Roots of the Nazi Mind (A. A. Knopf, Nowy Jork, 1941) stanowi dogłębną próbę przedstawienia powiązań między nazizmem i romantyzmem - która to linia argumentacji jest dla tego typu krytyki mocno istotna, jako że związek kontrkultury z tradycją romantyczną jest w naszym społeczeństwie oczywisty. Wreszcie, chcąc się zapoznać z zapiekłym potępieniem „nazistowskich chuliganów nowej wolności", zob. jadowity traktacik G. Legmana The Fake Revolt (Breaking-Point Press, Nowy Jork, 1967). 
się dla przemytnika alkoholu, tym etos purytański jest dla speca od pornografii: obaj czerpią zyski dzięki istnieniu opresywnej pruderiii ${ }^{30}$. Nawet tam, gdzie wspomniany prymitywizm służyć ma w charakterze narzędzia satyry tudzież stanowić należyta reakcję na zepsucie kultury dominującej, musi pojawić się moment, w którym ironiczne naśladownictwo niszczy ludzką wrażliwość i prowadzi do znieczulenia. Za niemal zniechęcające uznaję chwile, gdy natykam się na teksty w rodzaju poniższego: zabawnej (rave) recenzji muzyki grającej narkotycznego rocka grupy o nazwie The Doors (ochrzczonej tak ponoć pod wpływem Huxleya i Blake'a), opublikowanej w „Helix”, podziemnej gazetce z Seattle (lipiec, 1967):

The Doors. Ich styl opisać można jako wstępnie cunnilinguistyczny z domieszką wpływu Massacre of the Innocents. Elektryfikująco seksualna rzeźnia. Muzyczna krwawa łaźnia... The Doors są mięsożercami grasującymi w krainie muzycznych wegetarian... Ich kły, szpony i zwinięte skrzydła często znikają nam z oczu, lecz mimo że pozostawiając słuchacza wyczerpanym i z otartym kroczem, to przynajmniej uświadamiaja nam, że wciąż żyjemy. I pokazują zarazem, na czym polega nasze przeznaczenie. The Doors wykrzykuja w zaciemnionych salach to, co my wszyscy w podziemiu szepczemy jedynie w sercach: chcemy całego świata i to chcemy go NATYCHMIAST! (we want the world and we want it NOW!).

Nie może dziwić, że w obliczu takiego pozornie dionizyjskiego szału rozlegają się wołania zatroskanych o los „racjonalności”. W jaki zaś sposób mielibyśmy zyskać pewność, że badanie władz pozarozumowych nie zdegeneruje się do poziomu maniakalnego nihilizmu? Ta kwestia wymaga jeszcze rozpatrzenia i nie jestem przy tym pewien, czy dostatecznie wielu młodych poświęciło jej wystarczającą ilość czasu. Pozwólcie więc zatem, że zamknę niniejszy rozdział kilkoma myślami, które moga przysłużyć się wypracowaniu bardziej przystępnego, ale jak sądzę, nie mniej radykalnego, sensu naczelnego projektu kontrkultury.

Zadany problem stawia nas w obliczu znajomej, acz często nierozumianej dychotomii: przeciwstawienia rozumu i namiętności, intelektu

\footnotetext{
${ }^{30}$ „The Berkeley Barb” stał się szczególnie ponurym przykładem tego, co wynika z ignorowania faktów pozornie oczywistych. Na łamach pisma regularnie znajdujemy teraz mniej więcej trzy strony reklam filmów pornograficznych wraz z ogromną ilością ogłoszeń drobnych, dotyczących życia „aksamitnego podziemia”. Tego rodzaju handlarze obscena przyczyniają się do rozwoju wolności seksualnej mniej więcej tak, jak Dowództwo Lotnictwa Strategicznego - którego motto głosi „naszym zawodem jest czynić pokój” - wspomaga zdrowe stosunki międzynarodowe.
} 
i uczucia, głowy i serca... Owa kłopotliwa polaryzacja raz za razem narzuca się w dyskursie moralnym, ukryta pod maską rzeczywistego wyboru etycznego. Na czym jednak ten wybór polega? Żadna ze stron dychotomii nie jest, pod żadnym względem, jednoznacznie powiązana ze ściśle zdefiniowaną sfera osobowości. Raczej na poziomie dyskursu etycznego wybór sprowadza się najczęściej do wyboru pomiędzy modelami zachowania. Powiadamy przecież, że człowiek zachowuje się racjonalnie wówczas, gdy cechuje go wyzuta z emocji powściagliwość, niewzruszona roztropność oraz wyraźnie logiczne postępowanie. I odpowiednio, nazywamy ludzi nieracjonalnymi, kiedy ich zachowanie zarzuca beznamiętność na rzecz intensywnego i jawnego emocjonalizmu, namysł na rzecz impulsywności, jasność i logikę na rzecz entuzjastycznych deklamacji bądź innego rodzaju niewerbalnej ekspresji. Po wyznaczeniu powyższych ekstremów dalsza dyskusja przypomina zwykle wyliczankę przykładów i kontrprzykładów, których zadaniem jest wykazanie zalet i zagrożeń obu tych przeciwstawnych sposobów bycia.

Niektórzy ostrzegają przed grożącym racjonalności zalewem uczucia. Przypominaja o linczach i pogromach, o bezrozumnych ruchach masowych, o polowaniach na czarownice, jakim oddają się ludzie namiętni i żarliwi. Przypominaja nam, że Hitler stanowił jedynie echo słów D. H. Lawrence’a, który przykazywał swym wyznawcom, by „Myśleli własną krwia”. Przeciwko tego rodzaju barbarzyńskim wstrząsom rozum przywołuje przykłady wielkich humanistów: Sokratesa, de Montaigne’a, Woltera, Galileusza, Johna Stuarta Milla... oraz wielu innych, którzy bronili godności intelektu przeciwko zdziczeniu i przesądom swoich czasów.

Jeżeli jednak zastanowimy się raz jeszcze, to dostrzeżemy natychmiast, że tą samą linią argumentacji mogą się posłużyć zwolennicy modelu życia opartego na uczuciu. Czyż nie są w stanie każdemu aktowi gorącokrwistej brutalności, jaki miał miejsce w dziejach ludzkości, przeciwstawić przykładu równie odrażających zbrodni, popełnionych z krwią zimną? Czy gdyby trzynastowieczne chrześcijaństwo zostało zdominowane przez naturalne współczucie prostolinijnego św. Franciszka zamiast przez oziębły intelektualizm Innocentego III, mielibyśmy w ogóle do czynienia z inkwizycją? Przez jakiego pokroju ludzi zginęła męczeńską śmiercią św. Joanna - niewykształcona wizjonerka - jeśli nie przez bezdusznych manipulatorów, w których pełnię władz intelektualnych nie można wattpić? Ilu ludzi cechujących się niezrównaną racjonalnością może osiagnąć taki sam wynik, jaki ustanowili kwakrzy, wiedzeni wyłącznie moralną pasją i Światłem Wewnętrznym, w dyscyplinie opierania się wojnie, niewolnictwu i niesprawiedliwości społecznej? 
Rozpatrując przypadek najczęściej przywoływany w charakterze dowodu na niebezpieczeństwa niczym nieskrępowanej uczuciowości - przypadek nazizmu - można, moim zdaniem, posłużyć się argumentem tego samego rodzaju. Owszem, naziści istotnie stroili się w piórka zwulgaryzowanej odmiany romantyzmu. Gdy jednak zapytamy, jakiego typu ludzie zasilali ich szeregi, otrzymamy zgoła inny obraz tego reżimu. Nazistowskie państwo nie przetrwałoby nawet jednego roku bez do cna wyzutych z emocji, bez reszty racjonalnych technologów i administracyjnych automatów pokroju Adolfa Eichmanna. Ci, którzy dostrzegają w nazizmie deprawujący wpływ ruchu romantycznego, myla po prostu propagandowa powierzchnię z głębia politycznej rzeczywistości. Nowy Porządek ${ }^{31}$ nie był dziełem rozmarzonych poetów i dionizyjskich szaleńców. Odpowiada zań równie technokratyczny jak we wszystkich dzisiejszych technokracjach, starannie opracowany biurokratyczno-militarny aparat, oparty na nieograniczonym przymusie i precyzyjnie zarządzanym terrorze. Mimo że ruch ów odwoływał się do gorących namiętności mas, jego powodzenie wynikało z umiejętnej organizacji tych sentymentów w zdyscyplinowana maszynerię państwa, przy wykorzystaniu całego sprytu, jaki cechuje również naszych dzisiejszych badaczy rynku, manipulujących irracjonalnymi popędami komercyjnego społeczeństwa. Hitler pozował na Zygfryda, ale jego siepacze byli dziećmi lasu tylko w tej mierze, w jakiej potrafili dopilnować, by pociagi kursowały punktualnie. Poza wagnerowską fasadą nazistowski obóz koncentracyjny jawi się jako najwyższe osiagnięcie inżynierii społecznej, w obliczu której wołanie serca było systematycznie zagłuszane przez wymogi ludobójczej efektywności32.

By ten nasz katalog uaktualnić: w czym winniśmy upatrywać podstawowego niedostatku technicznych ekspertów, którzy obecnie administrują światową równowaga strachu? Czy właśnie intelektu brakuje naszym naukowcom, strategom i analitykom? Ludziom, którzy z bezosobowymi spojrzeniami kierują systemem masowego mordu, zdolnym do wywołania zniszczenia większego niż wszystkie linczujące tłumy i łowcy czarownic w dziejach: czy ich skaza jest niezdolność do racjonalnego myślenia?

\footnotetext{
${ }^{31}$ Nowy porządek (Neuordnung), nazistowski ład europejski - planowany przez niemieckich teoretyków faszyzmu, powojenny porządek polityczny w Europie, oparty na dominacji Rzeszy nad narodami uznanymi za „niższe”.

${ }^{32}$ Poruszający przykład tego, jak jeden prosty, pełen współczucia człowiek stawiał niemal męczeński - opór i nie powitał nazizmu z równą uległością jak liczne silniejsze od niego intelektualnie osoby, znajdujemy w dotyczącym austriackiego chłopa Franza Jaegerstaettera studium Gordona Zahna, In Solitary Witness (Holt, Rinehart and Winston, Nowy Jork, 1965).
} 
Wydaje się, że sedno sprawy uchwycił Lewis Mumford, gdy upiera się przy tym, że sytuacja stawia nas wobec czegoś, co można określić jedynie jako „racjonalność obłąkana” i przypomina nam o mrożącym krew w żyłach wyznaniu kapitana Ahaba: „Wszystkie środki, których używam, sa zdrowe, mój motyw i cel - obłąkane"33.

Słusznie wyczuwamy, że poważna dyskusja etyczna musi wykraczać poza dokonywane ad hoc oceny szczegółowych warunków - co stanowi zasadniczo obszar życia, jaki pozostawiamy prawu. Błądzimy wszakże jak sądzę - uznając, że dychotomia między tym, co racjonalne, a tym, co impulsywne - między działaniem przemyślanym a wiedzionym emocjami - pozwala podjać dyskurs na bardziej sensownym poziomie. Według mnie wzmiankowana dychotomia konfrontuje nas z czynnikami inherentnie nie-moralnymi. Ani racjonalność, ani emocjonalny impuls - jako charakterystyki modeli zachowania - nie gwarantują niczego pod względem etycznej wartości działania. Style owe konstytuują za to słownik zachowania, z którego możemy korzystać do wyrażania wielu rozmaitych rzeczy. Zatem przyznawanie któremukolwiek z nich prymatu na tym poziomie byłoby równie bezowocne, jak próba rozstrzygnięcia, czy proza, czy może jednak poezja jest medium bardziej właściwym dla wyrażania uczuć wyższych. Nie sądzę również, byśmy posuwali dyskusję do przodu, próbując wypracować w tej kwestii jakikolwiek połowiczny kompromis, wychodząc z założenia, że istnieje złoty środek pomiędzy rozumem a uczuciem, który gwarantowałby zachowanie właściwe. Dysponujemy zbyt wieloma przykładami całkowicie racjonalnej oraz bez reszty impulsywnej ludzkiej przyzwoitości, by odrzucić którykolwiek z tych modeli działania. Ani rozmodlonym świętym, ani humanistycznie nastawionym intelektualistom nie można odmówić etycznego piękna.

$\mathrm{Na}$ teren wnikliwej dyskusji o działaniu moralnym wkraczamy dopiero wówczas, gdy sięgamy pod powierzchnię modelu zachowania, za pomocą którego ludzie wyrażają własną etyczną wrażliwość, i poszukujemy ukrytego źródła, z jakiego wypływają ich działania. Jeżeli, po raz kolejny, uznamy zachowanie za słownik, zdołamy dostrzec, że nasz sposób korzystania z tego słownika jest całkowicie uzależniony od tego, co próbujemy swymi uczynkami „powiedzieć”. Nasze działanie wyraża całościową wizję życia - indywidualność i jej właściwe miejsce w porządku rzeczy - taka, jakiej najgłębiej doświadczamy. Wielu ludziom wizja owa może wydać się żałośnie zawężona, ze wszech stron ograniczona przez społecznie usankcjonowane zasady; tacy ludzie moga posiadać jedynie mglistą świadomość

${ }^{33}$ Mumford L. 1956. The Transformations of Man, Collier Books, Nowy Jork, s. 122. 
dobra bądź zła, która nie byłaby wytworem społecznej presji i przymusu. W takich sytuacjach człowiek zachowuje się w dany sposób wskutek strachu bądź zaszczepionego mu poczucia subordynacji, z niewielką tylko domieszką osobistych przekonań. Być może w ten sposób kształtuje się zachowanie większości - i stanowczo zbyt często takie właśnie zautomatyzowane posłuszeństwo wobec obowiązków uznajemy za postępowanie racjonalne i odpowiedzialne. Nawet jednak w tego typu warunkach, pod poziomem społecznie autoryzowanej moralności, majaczy jakiś pierwotny światopogląd, który dyktuje nam, czym jest rzeczywistość i co - w jej ramach - należy uważać za święte.

W wypadku większości z nas ów światopogląd może wymykać się słowom; może być czymś, na co nigdy nie kierujemy bezpośredniej uwagi. Może on pozostawać czysto podświadomym poczuciem naszej kondycji, które spontanicznie kształtuje percepcje i motywacje. Jeszcze zanim światopogląd pokieruje nas ku rozgraniczeniu pomiędzy dobrem a złem, nakłania nas do rozróżnienia tego, co rzeczywiste i nierzeczywiste, prawdy i fałszu, sensu i jego braku. Zanim podejmiemy jakiekolwiek działanie w świecie, musimy sobie ten świat wyobrazić, musi on pojawić się przed nami pod postacią sensownego schematu, do którego dostosujemy swe zachowanie. Jeżeli, niczym dżinijscy święci, uznamy wszelkie życie za święte, kłopotliwe unikanie każdego uczynku, który mógłby zaszkodzić najmniejszemu choćby owadowi, wyda nam się całkowicie rozsądne. Jeśli, z drugiej strony, uznamy wszelką nie-ludzką formę życia za niżej postawioną i mniej rozumną, stwierdzimy, że dżinista jest wysoce przesądny, a jego postępowanie nie poddaje się osądom moralnym. Co więcej, bez zmrużenia okiem wybijemy całe stada zwierząt dla własnej przyjemności lub wiedzeni potrzebą. Impulsywność lub rozwaga, z jaką ludzie robią tego rodzaju rzeczy, nie będzie miała tu żadnego znaczenia. O ile wrażliwość moralna człowieka pokrywać się będzie z naszym światopoglądem, przeważy w nas skłonność do uznania jego zachowania za słuszne i racjonalne. Żadna jednak najbardziej nawet rozumna argumentacja świata nie przekona nas, że ktoś, kto odrzuca naszą wizję rzeczywistości, nie jest szalony tudzież irracjonalny - aczkolwiek, owszem, możemy niekiedy wykazać się wobec takiej osoby pluralistyczna tolerancja, w pewnych określonych prawem granicach.

Nie dysponujemy w ramach naszej kultury stosownym językiem, w jakim moglibyśmy rozmawiać na temat poziomu osobowości, na którym rezyduje owa podstawowa wizja rzeczywistości. Wydaje się jednak bezdyskusyjne, że wywiera ona swój wpływ w miejscu położonym głębiej niż nasza świadomość intelektualna. Światopogląd nie jest czymś, czego się uczymy i co poznajemy w identyczny, świadomy sposób, w jaki poznajemy dowolne 
inne kwestie intelektualne. Przyswajamy go sobie raczej z perspektywy dominującego ducha czasów, bywamy nań nawracani lub uwodzeni przez doświadczenia, których nawet nie rejestrujemy. To światopogląd określa, co ostatecznie uznajemy za psychiczną normę. Dzięki tym wnioskom możemy zrozumieć, jak to możliwe, że dwaj ludzie tacy jak Bertrand Russell i Herman Kahn - z których żadnego nie można uczciwie oskarżyć o pogardę wobec rozumu, logiki czy intelektualnej precyzji - okazują się nieprzejednanymi antagonistami w tak licznych i doniosłych kwestiach. Sam Russell, starając się opisać prymat tak rozumianego światopoglądu nad wyuczonym stylem myślenia, mowy i zachowania, stwierdził: „Wolałbym oszaleć w prawdzie, niż być zdrowym w kłamstwie”. „Oszaleć” rzecz prosta z perspektywy innych, gdyż to, co przybliża człowieka do prawdy, staje się zawsze jego własnym standardem psychicznego zdrowia.

Kiedy piszę, że kontrkultura sięga do pozarozumowych aspektów osobowości, mam zawsze na względzie jej zainteresowanie tym poziomem, będące - na etapie zamysłu - jak sądzę projektem doniosłym. Ów projekt bez watpienia często niknie nam z oczu, zwłaszcza w otoczeniu bardziej zdesperowanych, młodych ludzi, którzy zbyt prędko dochodzą do wniosku, że antidotum na „obłąkaną racjonalność” naszego społeczeństwa sprowadza się do nurzania się w kolejnych szalonych pasjach. Podobnie jak nazbyt wielu z naszych poddanych surowej samodyscyplinie porządnych obywateli i „odpowiedzialnych” przywódców, młodzi pozwalaja swojemu rozumieniu zatrzymać się na etapie powierzchownego sposobu zachowania, za ostateczną przyjmując dychotomię pomiędzy „,spontanicznym” i „rozważnym” sposobem bycia. Sądzą również:

...iż to, co nieposzukiwane i natchnione przynależy jednostkom wyjątkowym, pozostającym w szczególnych stanach emocjonalnych; lub bawiącym się na imprezach osobom, pozostającym pod wpływem alkoholu czy haszyszu, nie dostrzegają w tym jakości charakteryzujacej całość doświadczenia. Z drugiej strony, zachowanie wyrachowane obiera sobie za cel dobra, niewynikające z konkretnych potrzeb bądź zachcianek jednostki, lecz istotne jedynie ze względu na coś innego (na tej zasadzie przyjemność sama w sobie tolerowana jest wyłącznie jako środek wiodący do zdrowia i efektywności). „Bycie sobą” oznacza w tym ujęciu zawsze działanie nierozważne, jakby pożądanie nie mogło posiadać racjonalnego sensu; a „zachowanie roztropne” oznacza samoograniczanie i stan znudzenia ${ }^{34}$.

${ }^{34}$ Zaczerpnięte z napisanej przez Paula Goodmana części pracy Perls F., Hefferline R., Goodman P. 1965. Gestalt Therapy, Delta, Nowy Jork, s. 242. 
Podczas jednak kiedy znaczna część naszej współczesnej kultury młodzieżowej dokonuje zwrotu w kierunku nieustannego szaleństwa i symulowanej bezmyślności, na jej scenie wciąż występuje zupełnie inne i znacznie bardziej dojrzałe pojęcie tego, na czym polegać ma badanie świadomości pozarozumowej. Bierze się ono przede wszystkim z silnego wpływu, jaki na młodych wywiera duchowość Wschodu, ze swym dziedzictwem łagodnego, spokojnego i na wskroś cywilizowanego nastawienia kontemplacyjnego. Oto jest tradycja, która radykalnie podając w wątpliwość zasadność i prawdziwość światopoglądu naukowego, prymat poznania rozumowego oraz wartość technologicznej skuteczności, czyni to tonem cichym i wyważonym, z humorem i czułościa, a nawet z pewną dozą przemyślnej argumentacji. Jeżeli umysł naukowy znajduje w tej tradycji cokolwiek odstręczającego, nie wynika to z niepodatności wschodnich religii na analizę i dyskusję. Wypływa to raczej z uznania przez nie intelektualnej wartości paradoksu i z przekonania, że analiza i dyskusja muszą ostatecznie ustapić przed doświadczeniem niepozwalającym się ująć w pojęciowe ramy. Orientalny mistycyzm pojmuje wartość argumentacji, lecz rezerwuje wiele miejsca dla milczenia, czyniąc to w oparciu o mądrze rozpoznany fakt, że to właśnie w milczeniu mierzą się ludzie z najważniejszymi chwilami swego życia.

Niestety, zachodni model umysłowości cechuje się skłonnością do traktowania milczenia jako braku słów sugerującego nieobecność sensu.

Nawet chcąc odrzucić światopogląd Laozi, Buddy i mistrzów zen, nie moglibyśmy oskarżyć ich o niedostatek intelektu, rozsądku czy brak szacunku dla wartości humanistycznych. Mimo że ich umysłowość nie koresponduje z naszą konwencjonalną nauką, to nigdy nie wtopią się oni w pałający żądzą linczu tłum, jak i nie wezmą udziału w domowej orgietce. Szczęśliwie, ich przykład nie uszedł uwadze naszej kontestującej młodzieży, co więcej, posłużył stworzeniu jednego z najsilniejszych nurtów kontrkultury.

Do tego prądu myślowego powrócimy w późniejszych rozdziałach. W tym momencie wystarczy stwierdzić, że badanie władz pozarozumowych zyskuje największe znacznie nie wówczas, kiedy ów projekt przeradza się w ogólną, rozmytą i barwną pyskówkę, lecz wtedy, gdy przybiera kształt krytyki światopoglądu naukowego, na fundamencie którego technokracja wznosi swą cytadelę, w jej cieniu zaś niknie z oczu nazbyt duża część naszych najbarwniejszych i najwspanialszych doświadczeń.

Przełoży: Grzegorz Komerski

Przejrzał: Tomasz Maślanka 